\title{
Orígenes de la Ortografía de la RAE: primeras aportaciones de Bartolomé Alcázar (1715) y de Adrián Conink (h. 1716)*
}

\author{
The origins of the Orthography of the RAE: The first \\ contributions by Bartolomé Alcázar (1715) and Adrián Conink (c. 1716)
}

\author{
Margarita Freixas \\ Universitat Autònoma de Barcelona \\ Margarita.Freixas@uab.cat
}

RESUMEN: El "Discurso proemial de la orthographía de la Lengua Castellana" publicado en los Preliminares del Diccionario de Autoridades (1726) constituye el primer tratado ortográfico elaborado por la Real Academia Española. La importancia de esta obra en el inicio del proceso de regulación ortográfica del español moderno justifica la necesidad de ahondar en su conocimiento a través de documentos hasta ahora no estudiados. Mediante el análisis del contenido de la copia de los discursos de Bartolomé Alcázar ("Sobre si la $Z$ es letra castellana", 1715) y de Adrián Conink ("Discurso de la Orthographía de la lengua castellana", h. 1716), conservada en el ms. 112 de la Biblioteca de la Real Academia Española, es posible conocer mejor los principios que sostienen las primeras reglas ortográficas de la Corporación. Para ello, no solo se tiene en cuenta la evolución de las normas desde sus primeras formulaciones por Alcázar y Conink hasta su redacción en el "Discurso proemial", sino también los acuerdos en materia ortográfica reunidos en las Actas (1713-1739).

Palabras clave: Ortografía, Real Academia Española, Bartolomé Alcázar, Adrián Conink, Diccionario de Autoridades.

\footnotetext{
* La investigación para este trabajo ha sido posible gracias a la ayuda de la DGICYT para los proyectos "Historia interna del Diccionario de la lengua castellana de la RAE (1817-1852)" (FFI2014-51904-P) y "El español en contacto con el catalán: variación diatópica y bilingüismo" (FF2012-33499), y el apoyo del Comissionat per Universitats i Recerca de la Generalitat de Catalunya al "Grupo de Lexicografía y Diacronía" (20145GR138). Asimismo, agradezco a los responsables de la Biblioteca y del Archivo de la Real Academia Española la hospitalidad y la ayuda recibidas para consultar los fondos de la Corporación.
} 
ABSTRACT: The "Discurso proemial de la orthographía de la Lengua Castellana" published in the Diccionario de Autoridades (1726) is the first orthography treatise of the Real Academia Española. The study of these documents which have not yet been studied allow us to increase our knowledge about the beginning of the normalization of modern Spanish orthography. The analysis of the lectures of Bartolomé Alcázar ("Sobre si la $Z$ es letra castellana", 1715) and Adrián Conink ("Discurso de la Orthographía de la lengua castellana", h. 1716) preserved in the ms. 112 of the Library of the Real Academia Española provides a better understanding of the first spelling rules of the Corporation. In this work, we consider not only the evolution of the spelling rules from its early formulations by Alcázar and by Conink until the final wording in the "Discurso proemial", but also the orthographic agreements collected in the Actas (1713-1739).

Keywords: Orthography, Real Academia Española, Bartolomé Alcázar, Adrián Conink, Diccionario de Autoridades.

\section{EL PROBLEMA DE LA ORTOGRAFÍA EN LOS ORÍGENES DE LA LABOR LEXICO- GRÁFICA DE LA REAL ACADEMIA ESPAÑOLA}

Con la publicación del Diccionario de Autoridades, la Real Academia Española no solo introdujo, para la lengua castellana, la metodología propia de la lexicografía moderna, sino que también inició una labor de establecimiento y difusión de normas ortográficas que ha dado lugar en nuestros días a un sistema gráfico muy estable y homogéneo en todas las áreas de habla hispana ${ }^{1}$.

En 1726, entre los Preliminares del Diccionario de Autoridades, se publicó el primer tratado ortográfico de la Real Academia Española, el "Discurso proemial de la orthographía de la Lengua Castellana"2, que reúne los principios y las reglas empleados en la impresión de esta obra lexicográfica. A principios del siglo XVIII, y a pesar de que ya se habían publicado diversos tratados sobre el tema, no existía un consenso en materia ortográfica y la convivencia de usos dispares dificultaba la redacción del Diccionario semasiológico. Para esta obra, resultaba fundamental establecer la grafía de los lemas que debían encabezar las entradas lexicográficas y servir de guía para presentarlas ordenadas alfabéticamente (Martínez Alcalde, 2001: 199 y 2007: 111-113; y Alcoba, 2012: 275).

\footnotetext{
${ }^{1}$ Para un recorrido histórico de las propuestas de regularización ortográfica del español desde la Edad Media hasta la época contemporánea, resulta aún muy útil Ángel Rosenblat (1951). Luis Fernando Lara (2000: 2), en su reseña a la reforma ortográfica de 1999 de la Academia Española, destaca que el consenso alcanzado en esta materia se debe a la "relativa cercanía de la ortografía del español a los sistemas fonológicos hispánicos" y a "las pequeñas pero constantes modificaciones que se han venido haciendo desde la gran fijación del siglo XVIII".

${ }^{2}$ Las citas al "Discurso proemial de la orthographía de la Lengua Castellana" proceden de la edición facsímil del Diccionario de Autoridades (Real Academia Española, 1990 [1726-1739]: LXI-LXXXIV).
} 
Por este motivo, en los primeros trabajos de los académicos, se encuentran ya referencias a la necesidad de consensuar un sistema ortográfico. Según Fernando Lázaro Carreter (2000 [1972]), la propuesta de redactar un tratado de ortografía debió de ser debatida en las juntas de 1715 (Actas, 25-IV-1715), pese a que

la idea no cobra cuerpo hasta mucho más tarde: Connink lee, en 1720 y 1721, sendos informes sobre el tema, que habrán de servir de base al discurso proemial sobre ortografía, incluido en los preliminares de la obra (Lázaro Carreter, 2000 [1972]:107).

Todos los trabajos consultados con referencias sobre la historia de la fijación ortográfica por parte de la Real Academia Española (Alcoba, 2012; Azorín, 2006; Blecua, 2006; Carriscondo Esquivel, 2006; Esteve Serrano, 1982; García Santos, 2011; Ferrer del Río, 1865; Lázaro Carreter, 2000 [1972]; Martínez Alcalde, 2010; Rosenblat, 1951; Sarmiento, 1978 y 2001; y Zamora Vicente, 1999) coinciden en señalar 1720 y 1721 como los años en que Adrián Conink presentó en las juntas una primera versión del tratado de ortografía que acabó por imprimirse entre los Preliminares del Diccionario de Autoridades (1726).

No obstante, estas fechas deberían adelantarse, pues el ms. 112 de la Biblioteca de la Academia Española contiene entre sus páginas 410 a 485 un "Discurso de la Orthographía de la lengua castellana", de Adrián Conink ${ }^{3}$, que puede datarse en 1716 gracias a una referencia temporal contenida en el texto. En el apartado dedicado a los usos de $\langle\mathrm{z}>$ y de $\langle$ ç $>$, el autor declara tener presente "el parecer que á instancia de la Real Academia dió el Reverendissimo Padre Bartholomé Alcázar el año passado de 1715 tocante á si la $z$ es ó no letra Castellana" (Conink, h. 1716: 455). Este texto puede fecharse con más precisión hacia el segundo semestre de 1716 si se tiene en cuenta la alusión de Conink a una propuesta suya en junta académica "con el motivo de la duda que se ofreció, sobre si el verbo dexar se debia escribir con $j$, ó con $x$ " (Conink, h. 1716: 478). Se trata de la delimitación de los usos de $<x>$ y de $<j>$ que expuso el 16 de julio de 1716 y que se refiere en las Actas $^{4}$.

El discurso de Conink conservado en el ms. 112 de la Biblioteca de la Academia Española debe de ser una copia de uno de los primeros borradores del tratado de ortografía que finalmente adoptó la Corporación. Junto a este texto, el ms. 112 conserva, en las páginas 114 a 120, una copia del discurso "Del P. Bartholomé Alcázar sobre si la $Z$ es letra castellana" ${ }^{5}$ datado el 6 de abril de

${ }^{3}$ La autoría del discurso se identifica mediante la atribución a "D. D. A. C." al final del título.

${ }^{4}$ Cfr. en $\$ 4.4$ la transcripción del acuerdo tomado en la junta académica del 16-VII-1716 sobre la distribución de las grafías $\langle x>y<j>$.

${ }^{5}$ Alonso Zamora Vicente (1999: 71) recoge la noticia de que "la biblioteca académica conserva un manuscrito del padre Alcázar Sobre si la $Z$ es letra castellana, firmado en San Clemente (Cuenca) en 1715", aunque no indica su signatura. Sobre la labor de Bartolomé Alcázar, véase Antonio Pérez Goyena (1922) y Zamora Vicente (1999: 70-71). 
1715 (Alcázar, 1715: 1206). Alcázar envió este trabajo a la Academia desde San Clemente (localidad a la que se trasladó entre finales de 1714 y principios de 1715 por problemas de salud). Su contenido se leyó en la sesión del 25 de abril de $1715^{7}$ y, según nos informan las Actas, pretendía responder a las inquietudes que en materia ortográfica había manifestado José Casani a Bartolomé Alcázar. Así, Alcázar señalaba, en carta a la Academia, que escribió su discurso a raíz

de haberle escrito el mismo Padre Casani que en la Academia se había hablado algunas veces de la necesidad que hay de formar un tratado de Ortografía para fijar muchas cosas en que cada día se ofrecen dudas, por la variedad que ha habido en el escribir, y especialmente sobre el uso de la $Z$ y la $C$ y la equivalencia entre la $B$ y la $V$ consonante (Actas, 25-IV-1715).

Esta noticia dio pie a Fernando Lázaro Carreter (2000 [1972]: 107) a señalar la preocupación temprana de la Academia Española por la redacción de un tratado de ortografía. En este sentido, señala la existencia de una "Disertación académica en que se pretende probar que, para el más perfecto conocimiento de las voces, es conveniente arreglar la ortografía de ellas a sus orígenes", obra de Vincencio Squarzafigo, leída en la junta del 26-V-1718 (Actas) y de la que, según Lázaro Carreter, la Corporación conserva un texto manuscrito 9 .

\footnotetext{
${ }^{6}$ La fecha se encuentra al final del texto: "San Clemente y Abril 6 de 1715. Bartholomé Alcázar".

${ }^{7}$ Las Actas no recogen los comentarios que pudo suscitar este texto. Solo indican que se leyó en junta académica y que se resolvió guardar el escrito para cuando se tuviera que trabajar en este asunto.

${ }^{8}$ En esta contribución modernizo, según la norma actual, la ortografía, la acentuación y la puntuación de los pasajes de las Actas de la Academia Española, documentos que pueden consultarse en el Archivo de la Corporación, pero de los que no se puede obtener una copia. La dificultad que supone transcribir paleográficamente estos textos, unida a que las Actas representan solo los usos gráficos del Secretario (que no solía ajustarse a las normas de los primeros impresos de la Academia Española), explica que, como Fernando Lázaro Carreter (2000 [1972]) y José Manuel Blecua (2006), me decante por su modernización gráfica. En la transcripción de pasajes de las Actas mantengo, no obstante, la grafía original de las voces cuya ortografía se discute ( $v$. g. dexar, Actas, 16-VII-1716) y que destaco en cursiva. En cambio, reproduzco fielmente las citas del Diccionario de Autoridades (sin modernizaciones ni regularizaciones en la representación de las grafías y de la puntuación) y de sus Plantas, dado que la Real Academia Española se propuso, desde sus primeras publicaciones, que sus escritos constituyeran un modelo ortográfico (Rosenblat, 1951: LXII-LXXI). Asimismo, transcribo sin cambios las citas del ms. 112, por haber podido obtener una copia del texto. Únicamente, y para facilitar la lectura de las citas, elimino el subrayado utilizado en ocasiones e introduzco la cursiva para señalar las letras o las palabras que son objeto de comentarios metalingüísticos. En la transcripción de las fuentes gramaticales no académicas, respeto las grafías y la puntuación de las ediciones consultadas.

${ }^{9}$ Una errata explica que la fecha de lectura de la disertación de Squarzafigo sea el 26-V-1728 en los datos que reúne Fernando Lázaro Carreter (2000 [1972]: 106) y no el 26-V-1718, como he confirmado en una lectura de las Actas. No he podido consultar el manuscrito al que se refiere Lázaro Carreter, ni tampoco parece haber accedido a él Francisco Carriscondo Esquivel (2006: 241-294), quien lo menciona para subrayar la importancia de la labor del primer secretario de la Academia en el establecimiento y aplicación de las primeras reglas ortográficas de la Corporación (véanse las pp. 250 y 268-273).
} 
El estudio de los discursos de Bartolomé Alcázar y de Adrián Conink conservados en el ms. 112 de la Biblioteca de la Real Academia Española resulta fundamental para reconstruir la historia del establecimiento de las primeras normas ortográficas por parte de la Corporación. Por este motivo, en este trabajo se pretende analizar estos textos en comparación con la versión final del "Discurso proemial de la orthographía de la Lengua Castellana”, publicada en el Diccionario, con el fin de ahondar en el conocimiento de los principios de la teoría ortográfica de la Academia Española en sus orígenes y desentrañar el proceso de redacción de reglas para fijar usos gráficos.

En las páginas siguientes, contextualizaré los trabajos de Alcázar y de Conink conservados en el ms. 112 en el marco de las labores de preparación de los materiales del primer tomo del Diccionario de Autoridades (véase $\S 2$ ). En segundo lugar ( $\$ 3$ ), examinaré los principios teóricos que sustentan las propuestas de Alcázar (1715) y de Conink (h. 1716), en comparación con el "Discurso proemial de la orthografía" (1726). Finalmente $(\S 4)$, analizaré el proceso de establecimiento de reglas ortográficas para distinguir los usos de grafías unísonas. Para ello, tendré en cuenta las propuestas ortográficas de Alcázar y de Conink en los textos conservados en el ms. 112 de la Biblioteca de la Real Academia Española, las reglas del "Discurso proemial de la orthografía" y las discusiones sobre cuestiones ortográficas reflejadas en las Actas.

\section{LA ORTOGRAFÍA EN LA PREPARACIÓN DEL DICCIONARIO DE AUTORIDADES}

Las reflexiones sobre la ortografía acompañaron, desde sus inicios, el trabajo de redacción del Diccionario de Autoridades. En la primera versión de la Planta de esta obra — presentada en la junta del 10-VIII-1713 y elaborada por Andrés González de Barcia $^{10}$ —, se señalaban ya las dificultades que suponía establecer la grafía de las palabras. Así, en $\S 4$ se advertía que, en el Diccionario, debía darse "La razon de la Orthographia, y si se ofreciere alguna dificultad sobre ella, desvanecerla" y en $\S 6$, que era preciso "Anotar las Variedades que aya en el escribir" (Actas, 10-VIII-1713).

En una segunda y definitiva redacción de la Planta, redactada por Bartolomé Alcázar, José Casani y Andrés González de Barcia, y presentada y aprobada en la sesión académica del 2-XII-1713, se incluyó una norma ortográfica de carácter general:

Observar exactamente la Orthographía de las Voces, de suerte que no se obscurezca su primitivo orígen, desterrando los abúsos que en contrário se hallaren (Real Academia Española, 2010 [1713-1726]: 451, § 13).

${ }^{10}$ La transcripción de la Planta de González de Barcia se encuentra en las Actas (10-VIII1713), en Fries (1989: 26-27) y en Freixas (2010: 448-449). 
Se trataba de un criterio inspirado en la práctica lexicográfica de la Académie Française de optar por una ortografía etimologizante que permitiera reconocer "l'origine des mots"11. En la Planta esta regla general se acompañaba de otra en la que se reconocía la necesidad de reunir en el Diccionario "las variedades que se hallaren en el escribir algunas Voces, aprobando la mejor, y desechando las demás" (Real Academia Española, 2010 [1713-1726]: 451, § 17; Ruhstaller, 2002).

Las recomendaciones de la Planta bien pronto se consideraron una guía insuficiente. En materia ortográfica, como se ha señalado en $\S 1$, Bartolomé Alcázar (1715), Vincencio Squarzafigo (1718) y Adrián Conink (desde 1716 a 1726) realizaron aportaciones en forma de discursos o tratados breves. Sin duda, la contribución más importante sobre este tema fue la del académico Adrián Conink.

Los estudios sobre la ortografía y la historia de la Academia — sin datos sobre el texto de Conink conservado en el ms. 112 de la Biblioteca de la Corporación - se refieren a los trabajos de Conink a partir de 1720 (véanse especialmente Ferrer del Río, 1865: 91; Esteve Serrano, 1982: 60-62; Blecua, 2006: 47; Carriscondo Esquivel, 2006: 369; Martínez Alcalde, 2007: 112, y últimamente González Ollé, 2014: 133-148). En julio de 1720 Conink leyó una versión de su discurso sobre la Ortografía, y el 19 de septiembre de 1720

trajo impreso el papel que compuso sobre los puntos de Ortografía, y leyó en las Academias de 11 y 25 de julio, y le repartió a los señores académicos, dando juntamente un ejemplar para que se guardase en la Secretaría (Actas, 19-IX-1720; reproducido en Esteve Serrano, 1982: 60).

No tenemos noticias de que se conserve este impreso. Medio año más tarde, Conink confió a la Academia una nueva redacción del texto (Actas, 6-II-1721 y Esteve Serrano, 1982: 60). El 10 enero de 1724 (Actas), cuando se decidió el contenido de los Preliminares del Diccionario de Autoridades, se encargó a Conink la redacción definitiva del "Discurso de la Orthographía". En julio de 1724 (Actas, 8-VI-1724 y 12-VI-1724) se revisó el texto preparado, que Conink entregó terminado el 11 de septiembre de 1724 (Actas y Esteve Serrano, 1982: 61). Este tratado se consideró tan útil que se planteó que se publicara en un folleto de distribución entre los académicos, posibilidad que se desestimó

atendiendo a que por más que se quisiese tener oculto hasta que salga el Diccionario no se podría quizá conseguir, y se le quitaría a la obra principal el lucimiento que le puede añadir esta agregada" (Actas, 14-IX-1724; Esteve Serrano, 1982: 61).

\footnotetext{
${ }^{11}$ Véanse las referencias a la etimología de las palabras en el "Préface" a Le Dictionnaire de l'Académie Françoise (Académie Française, 1997 [1694]: fol. ẽ ij ${ }^{\mathrm{r}}$ ). Cfr. Ángel Rosenblat (1951: LXX-LXXI) sobre la influencia de l'Académie Française.
} 
El discurso de Conink se revisó de nuevo a principios de 1726 por José Casani y Miguel de Perea, quienes prepararon un informe de "reparos" que se debatió en una junta (Actas, 21-II-1726). Conink no pudo participar en esta sesión, por estar ya muy enfermo (Actas, 21-II-1726). Así, tras incorporar las enmiendas propuestas, el 28 de febrero de 1726 Casani confió el texto definitivo al Secretario, Vincencio Squarzafigo, encargado de "ponerlo en limpio y prepararlo para la impresión" (Actas, 28-II-1726).

No tenemos constancia de que se hayan conservado versiones intermedias del "Discurso de la Orthographía de la Lengua Castellana" entre la que suponemos una de sus primeras redacciones (hacia 1716), copiada en el ms. 112 de la Academia Española, y la última, publicada entre los Preliminares del Diccionario de Autoridades (1726).

Como indica esta reseña del proceso de redacción del primer tratado ortográfico de la Real Academia Española, su importancia para el Diccionario de Autoridades y las dificultades que ofrecía la fijación ortográfica a principios del siglo XVIII explican la existencia de numerosas versiones del "Discurso proemial de la orthographía de la Lengua Castellana” y que este se revisara profusamente.

\section{LA EVOLUCIÓN DE LOS PRINCIPIOS ORTOGRÁFICOS EN LOS ORÍGENES DE LA REAL ACADEMIA ESPAÑOLA}

Las contribuciones de Bartolomé Alcázar y de Adrián Conink conservadas en el ms. 112 constituyen los primeros intentos por alcanzar un sistema homogéneo de representación ortográfica para los textos de la Real Academia Española. Según se reconoce en el "Discurso proemial de la orthographía", en un principio, solo se pretendía establecer una ortografía para la redacción del Diccionario de Autoridades:

Esto es lo que ha parecido à la Academia advertir, para reglar la Orthographía para su uso, y fijar el méthodo que ha guardado en su Diccionario: à fin de que límpio de los defectos que la variedád de los génios ha introducido en la Léngua, logre esta hermosúra y esplendór que tanto se debe à su puréza y elegáncia” (Real Academia Española, 1990 [1726]: LXXXIV) ${ }^{12}$.

\footnotetext{
${ }^{12}$ La novedad del sistema gráfico propuesto por la Academia Española explica que se reimprimieran los dos primeros pliegos del Diccionario de Autoridades, "habiendo reconocido tener algunas erratas a causa de no estar prácticos los oficiales de la Imprenta en la Ortografía que la Academia ha resuelto establecer" (Actas, 26-X-1724; cfr. Lázaro Carreter, 2000 [1972]: 127-128). Y, como recuerda Rosenblat (1951: CXXIV-CXXV), las normas de la Real Academia Española no tuvieron un uso generalizado, más allá de la redacción de sus propias obras, hasta que "una Real Orden, del 25 de abril de 1844, impone la ortografía académica en la enseñanza". Rivas Zancarrón (2010: 327-348) demuestra cómo las reformas ortográficas de la Academia Española
} 
Si bien los textos de Alcázar y de Conink comparten el objetivo de establecer reglas para la escritura de las obras de la Academia Española, el alcance de sus contribuciones es muy distinto. El texto de Alcázar se limitaba a discutir los usos de $<\mathrm{z}>$ (Alcázar, 1715: 114-119) y de $<\mathrm{b}>$ y $<\mathrm{v}>$ (Alcázar, 1715: 119120); mientras que el de Conink trataba, por un lado, de asentar los principios que permitieran unificar la ortografía de los textos académicos y, por el otro, de establecer reglas de uso para las grafías unísonas.

No obstante, en ambos discursos es posible desentrañar los principios que sustentan un modelo de representación gráfica. Por consiguiente, en este apartado, me centraré en el análisis de los criterios que subyacen a la redacción de normas y, en el siguiente, en el estudio de las reglas ortográficas para las distintas letras.

Bartolomé Alcázar justificó sus ideas en materia ortográfica recurriendo a criterios tradicionales. Otorgaba especial importancia a los usos consolidados y a la etimología. Por ello, al delimitar los usos de $<\mathrm{z}>$ demostró, en primer lugar, que se trata de una letra "castellana". Este reparo solo se comprende si se tiene en cuenta que los académicos consideraban la tradición latina un modelo para fijar la ortografía. En el latín clásico, la $<x>$ era la última letra del alfabeto y la $<\mathrm{z}>$ se empleaba solo para transcribir palabras griegas ${ }^{13}$. Alcázar defendió que la $<z>$ es letra castellana, sin referirse a su uso para representar en romance los sonidos derivados de los grupos latinos $T \breve{I}, T \breve{E}, C \breve{I}$ y $C \breve{E}$; y aludió, en cambio, a la tradición escolar:

la misma cartilla con que a los que vivimos, a nuestros Padres y Abuelos se enseñó a leher en la escuela haze notoria evidencia de ser la $Z$ letra castellana, pues nos la pone en su Abecedario, aunque la última (Alcázar, 1715: 114).

Asimismo, desaconsejaba el uso de la "ç castellana" por tener menor raigambre en la tradición ortográfica española y un uso limitado, ya que "se inbentó para suavizar la aspereza de la $C$, quando hiere a las vocales $a, o, u, \mathrm{y}$ para que en lugar de $c a, c o, c u$, se pronuncie ça, ço, çu” (Alcázar, 1715: 118) ${ }^{14}$.

penetran en los impresos a lo largo del siglo XVIII, mientras que en los manuscritos perviven las alternancias. Martínez Alcalde (2012) explica el paulatino proceso de institucionalización de la ortografía académica como referente en la enseñanza.

${ }^{13}$ Cfr. Salvador y Lodares (2001 [1996]: 363-364). Se trataba, no obstante, de una grafía extendida desde los orígenes de la escritura romance (Rosenblat, 1951: XII; Torrens, 2006, donde se encuentra una revisión de los estudios clásicos sobre los usos de $<\mathrm{z}>$ y de $<$ ç $>$ en los primeros textos romances).

${ }^{14}$ En realidad, la $<c ̧>$, originada en la escritura visigótica, se empleó desde el s. XIII para diferenciar una realización sorda en oposición a la sonora, con $<\mathrm{Z}>$ (Torrens, 2006: 1386-1388). Como es sabido, "la diferencia en la pronunciación de $<c ̧>$ y $<\mathrm{z}>$ se borra a fines del siglo XVI y principios del XVII, pero la diferencia ortográfica se prolongó hasta el siglo XVIII" (Rosenblat, 1951: XII). 
Para establecer los usos de $<\mathrm{b}>$ y de $<\mathrm{v}>$, heredadas del latín, Alcázar reclamaba acudir a la etimología, ya que ambas se pronuncian en español del mismo modo, rasgo que consideraba un "vicio [...] innato de nuestra Nación" (Alcázar, 1715: 119). El criterio etimológico aseguraba la proyección internacional del español, pues los extranjeros valorarían positivamente las reglas que tomaran como modelo el latín, lengua de prestigio para la intercomunicación entre naciones:

Mas porque esté en lo escrito [refiriéndose a la confusión de $\langle\mathrm{b}\rangle \mathrm{y}\langle\mathrm{v}\rangle$ ] se hace más universal y pasa de nuestra nación a las otras es justo que le procuremos correjir en quanto cupiere, para que sea menor nuestro desdoro, ni beo otro camino más llano que observar exactamente la legítima Orthographía de los orígenes de las voces, mientras pudiéremos, porque de esta suerte, aunque pronunciemos mal, por lo menos escriviremos bien, y no tendrán los Estrangeros el motivo de zensurar lo bien escrito que tienen para lo mal pronunciado (Alcázar, 1715: 120).

La fijación del principio etimológico para la escritura de $\langle$ b $>$ y de $\langle$ v $>$ se mantuvo en el "Discurso de la Orthographía de la lengua castellana" de Adrián Conink (h. 1716) con los mismos argumentos:

La mayor dissonancia [...] es la confusion bárbara, con que á todas horas, sin el menor reparo, se hallan promiscuamente usadas la $u$, consonante[,] y la $b$, teniendo á lo menos para casi todas las voces reglas competentes, para conocer quando se deba usar de la $v$ consonante, y quando de la $b$. Es assi, que los Españoles no ponemos aquel cuidado en la pronunciacion de la $b$. que especialmente ponen entre otros los Italianos, [...] pero esto no se opone á que pudiendose facilmente separar, y no confundir en lo escrito, se dexe de practicar [...] contra todas reglas de perfecta Orthographia, (Conink, h. 1716: 450-451).

Esta afirmación de Conink — como todas las referidas a los usos de otras letras unísonas (véase § 4) — se encuentra en la parte final (Conink, h. 1716: 445-485) de un tratado cuyas reglas ortográficas van precedidas de una extensa introducción en la que se desarrollan dos cuestiones centrales. En primer lugar, se justifica la necesidad de que la Academia Española establezca unas reglas ortográficas (Conink, h. 1716: 410-421); en segundo lugar, se exponen los principios que deben seguirse para fijar dichas normas (Conink, h. 1716: 421-445) ${ }^{15}$.

\footnotetext{
${ }^{15}$ En el "Discurso proemial de la orthographía de la Lengua Castellana" (Real Academia Española, 1990 [1726-1739]: LXI-LXXXIV), se tratan los aspectos analizados en el "Discurso de la Orthographía de la lengua castellana" de Conink (h. 1716), aunque con una extensión distinta. A la parte introductoria sobre la utilidad de la ortografía se le dedica apenas una página (p. LXI). A continuación, se añade un apartado (§ I) destinado a la puntuación y a la acentuación (aspecto que no se trata en la primera versión del discurso de Conink) sobre el "Modo de puntuar las cláusulas, señalar los accentos, y escribir donde toca letras mayúsculas, ò versáles” (pp. LXII-LXV). Tras la puntuación, se discuten los criterios para establecer normas ortográficas en dos apartados,
} 
La comparación entre las dos primeras partes del primer discurso de Adrián Conink con la Introducción y los epígrafes II y III del "Discurso proemial de la orthographía de la Lengua Castellana” permite descubrir la existencia de una evolución en algunos aspectos clave de las primeras normas ortográficas impulsadas por la Real Academia Española.

El discurso manuscrito parte de la constatación de la existencia de una notable variación gráfica en los manuscritos e impresos españoles:

Es tal la variedad, con que los Autores Españoles, assi antiguos como modernos, han usado dela Lengua Castellana; que parece han tirado en sus obras, mas á confundir su Orthographia, que á fijarla y establecerla (Conink, h. 1716: 410).

Esta idea se recoge también en el inicio del epígrafe II del "Discurso proemial":

En lo que hai, y se experimenta notable desigualdád en la Orthographía de la Léngua Castellana es en el modo de escribir las palabras, porque cada uno ha usado del méthodo que le ha dictado su génio y manéra de hablar, ò segun los priméros rudimentos que aprendió en la escuela quando niño, ù despues el uso le ha ido enseñando, sin atender à otra regla que à la común y vulgar (Real Academia Española, 1990 [1726]: LXV).

La divergencia de usos gráficos en los autores no solo dificultaba el trabajo lexicográfico, sino que debía combatirse en atención a la claridad y a la necesidad de competir con otras lenguas. En varias ocasiones, Conink se refería a la "confusion que ocasiona la diversidad de lo escrito, asi en los proprios como en los extraños", (Conink, h. 1716: 411). Asimismo, se lamentaba de la desventaja que suponía carecer de principios ordenadores de la ortografía como los que disponían otras lenguas clásicas y romances —-"las Lenguas Hebraica[,] Syriaca, Griega, Latina, y sus derivadas la Jtaliana y Francesa" (Conink, h. 1716: 411412)_, con "reglas, y modos fixos para practicarse" (Conink, h. 1716: 412).

Los argumentos aquí expuestos, que no se desarrollan con tanta extensión en el "Discurso proemial de la orthographía de la Lengua Castellana", se hallan, no obstante, entre las razones subyacentes para su elaboración, ya que están de

\footnotetext{
destinados a rebatir las opiniones de tratadistas anteriores (§ II, "Dificultad de fijar la Ortographía, y falsedád de várias reglas generales que han pretendido establecer algunos Autóres", pp. LXVLXVIII) y a exponer las propuestas de la Real Academia Española (§ III, "Causa de la variedád y confusión en la Orthographía, y algunos presupuestos en que se explican y assientan várias reglas para mayor claridád de las generales, que se darán despues", pp. LXVIII-LXXI). Finalmente, se trata de las grafías unísonas ( $§ \mathrm{IV}$, "De las letras unísonas, ò que se equivocan en la pronunciación", pp. LXXI-LXXV), las consonantes dobles ( $\mathrm{V}$, "Del uso de la duplicación de las letras", pp. LXXV-LXXIX) y los grupos consonánticos (§ VI, "De la concurréncia de diversas consonantes", pp. LXXIX-LXXXIV).
} 
acuerdo con los motivos aducidos para redactar el Diccionario de Autoridades. Esta obra, como la Ortografía, se concibió como una herramienta para mejorar el conocimiento de la lengua por parte de "proprios" y de "extrangéros". Se consideraba que, antes de su publicación,

la Lengua Españóla, siendo tan rica y poderosa de palabras y locuciones, quedaba en la mayor obscuridad, pobreza è ignoráncia, aun de los próprios que la manejan por estúdio, y remóta enteramente à los extrangéros, sin tener otro recurso, que el libro del Thesoro de la Léngua Castellana, ò Españóla, que sacó à luz el año de 1611. Don Sebastian de Covarrubias (Real Academia Española, 1990 [1726-1739]: I, "Prólogo", p. I).

Asimismo, recuérdese que la superación de las obras lexicográficas publicadas con anterioridad por otras naciones es el acicate que los académicos reconocían que les había impulsado a la redacción del Diccionario (Fries, 1989: 5355, Álvarez de Miranda, 2000: 37 y Freixas, 2010: 50):

...se consideraba era poco áire de nuestra Nación estar sin este adorno, quando de este género de libros [los diccionarios], en que se explican las voces de las lénguas natívas, se insinúan sus orígenes, y se aproprian las phrases, el Autor mas antíguo, que se reconoce en la República literária, fué el Español Don Sebastian de Covarrubias, que con novedád publicó este méthodo. Su libro ha merecido la estimación de próprios y Extrangéros; pero como es facil al ingénio añadir y limar lo mismo que se halla inventado: los Franceses, Italianos, Ingleses y Portugueses han enriquecido sus Pátrias, è Idiómas con perfectissimos Diccionarios, y nosotros hemos vivido con la glória de ser los primeros, y con el sonrojo de no ser los mejores (Real Academia Española, 1990 [1726-1739]: "Historia de la Real Academia Española”, I, p. XI).

Tras defender la necesidad de fijar la ortografía, Conink analizó los tratados anteriores sobre este tema y defendió la autoridad de las nuevas normas de la Academia. En el "Discurso proemial" se omitieron los nombres de los tratadistas mencionados por Conink (h. 1716) —Bartolomé Jiménez Patón, "la Gramática Española del Licenciado Villalon" (Villalón, 1558) y "las oservaciones del Maestro Juan de Miranda, sobre el uso de la Lengua Castellana" (Miranda, 1566)_, a excepción de Antonio de Nebrija.

Además de las diferencias existentes en el repaso de las propuestas de regularización ortográfica anteriores a la Academia, destaca el hecho de que, en la versión definitiva del tratado, se omitan o mitiguen algunos argumentos del texto manuscrito. Se trata, en concreto, de: la insistencia en la condena de la variedad gráfica en los textos de los "autores"; la mención a la lengua de la Corte como un modelo socialmente reconocido que no puede, sin embargo, imponerse; y la comparación entre el grado de fijación alcanzado por el latín y por otras lenguas modernas respecto al español. 
En cuanto al primer punto, la variación gráfica de los autores, no es solo el motivo que, como ya se ha señalado, sirve de arranque al discurso, sino que se trata de un tema recurrente. En varias ocasiones, Conink se lamentaba de la falta de sistematicidad en los usos gráficos, que se manifestaba en un grado extremo cuando se documentaban formas distintas de un mismo vocablo en los textos de un mismo autor:

lo que causa notable extrañeza, es la irregularidad con que en un mesmo Autor, y en una mesma obra, y á veces en una mesma plana, se hallan escritas diferentemente unas mesmas palabras (Conink, h. 1716: 417-418).

No se encuentra disculpa a esta práctica. No es posible excusarla bajo "el pretexto de ser erratas de imprenta", ya que "muchos libros fueron corregidos, y emendados por sus Autores" y "en los mesmos originales escritos por su mano, se reconoce [...] esta falta" (Conink, h. 1716: 418). Tampoco era razonable justificar a los autores con el supuesto de que debieron de ocuparse más del contenido de sus textos, de la argumentación y de la selección del léxico, que de la forma gráfica, considerándola "como de corta entidad, ó como voluntaria, y dependiente del dictamen, y arbitrio de cada uno" (Conink, h. 1716: 419), pues de este modo se atentaba a la "hermosura" de la lengua:

la hermosura de las Lenguas pende en gran parte de la puntual, y exacta formacion de las dicciones, assi como de la perfecta symetria lo exquisito, y excelente de la Pintura (Conink, h. 1716: 419-420).

Finalmente, la falta de coherencia en los usos gráficos de los autores resultaba aún más reprobable si se tiene en cuenta que el origen de la lengua española no es desconocido y que puede acudirse a la etimología como guía para la escritura:

¿Valieronse por ventura de términos extraños, y diversos de los de que se compone la Lengua; ó los suyos estaban tan adulterados y mudados que del todo de ignorasen sus principios para que cada uno pudiesse usar libremente de ellos, coforme le dictase su genio, sin el menor respecto al origen de donde proceden? (Conink, h. 1716: 420-421).

Estas palabras no pretendían cuestionar el prestigio de los autores, sino que planteaban un problema metodológico de gran calado, pues si el modelo de lengua que pretendía mostrar la Academia Española en su primer Diccionario era el de los autores, ¿cómo debían interpretarse las alternancias gráficas documentadas? A través de ejemplos, Conink mostraba las dificultades que suponía la fijación de la grafía de los lemas cuando las autoridades presentaban usos vacilantes. Es el caso de acechar:

para que se eche de ver á lo que llega la suma variacion; y desigualdad en el modo de escribir, basta para prueba decir, que esta voz acechar se halla es- 
crita, á lo menos, de cinco modos, porque Antonio de Nebrixa, Don Bernardo de Alderete, Lope de Vega, y otros, la escriben con dos ss. diciendo assechar; Don Sebastian de Covarrubias; Don Francisco de Quevedo, y otros, unas veces con $c$, otras con $z$, y otras con $c ̧$; y el Obispo Manero la trahe con $h$, escribiendo hazechar en su Apologia de Tertuliano (Conink, h. 1716: 416).

Conink, que no resuelve cómo debe regularizarse la escritura de estas formas - caso que se solventa en el Diccionario de Autoridades con la inclusión del doblete acechar y assechar ${ }^{16}$ _, pretendía subrayar el problema de interpretación que suponen las variantes gráficas y legitimar, a su vez, que el criterio de la Academia Española deba imponerse ante la falta de homogeneidad de la tradición gráfica.

La insistencia con que Conink (h. 1716) aludía a las alternancias gráficas en textos de autores reputados (tema con menor presencia en el tratado preliminar del Diccionario de Autoridades) muestra cómo esta versión del discurso está más apegada a los problemas de fijación de las grafías que se presentaban en la práctica lexicográfica. En este sentido podrían interpretarse también las sucesivas menciones a la lengua hablada y a la lengua de la Corte como una búsqueda de referentes en el camino hacia la fijación ortográfica.

En el discurso de Conink de hacia 1716 la lengua hablada tenía especial importancia, pues dedicaba mucha atención a rebatir la premisa de tratadistas anteriores —entre los que destaca Bartolomé Jiménez Patón ${ }^{17}$ — de que "la única, y segura regla, para reducir á escrito la Lengua Castellana, es escribir lo que se habla, y pronuncia, respecto de que solo lo que se pronuncia, y habla, es lo que constituye las Lenguas, y las hace entre sí diversas" (Conink, h. 1716: 426) ${ }^{18}$.

16 Para el origen, usos y variantes gráficas de acechar ('Mirar con particulár cuidado y cautelosa atención desde alguna parte oculta...', Diccionario de Autoridades, s. v. acechar) y asechar ('Disponer artificiosamente, con malicia y engáño encubierto, alguna trama para hacer daño à otro...', Diccionario de Autoridades, s. v. assechar) véase Joan Coromines y José Antonio Pascual (2012 [1980-1991]: s. v. acechar).

17 Como ha sido bien estudiado (Rosenblat, 1951 y Esteve Serrano, 1982), la tradición ortográfica que arranca con Antonio de Nebrija, basada en el principio de Quintiliano de escribir como se pronuncia, tuvo notables seguidores, como Mateo Alemán y Gonzalo Correas (Bustos Tovar, 1988), que no se citan ni en el texto manuscrito de Conink ni en el "Discurso proemial", aunque la Ortografía castellana (1609) de Alemán se incluye en la "Explicación de las abreviaturas de los nombres de Autóres y obras" de los vols. III y IV del Diccionario de Autoridades. En el extremo opuesto, no fueron pocos los que en el siglo XVII — como Juan de Robles y Gonzalo Bravo Grajera, no citados en el Diccionario de Autoridades- defendieron una ortografía basada en la etimología. En el camino intermedio estaban las propuestas de Juan López de Velasco (Orthographia y pronunciación castellana, 1582) y de Bartolomé Jiménez Patón, muy bien valorados en el Diccionario de Autoridades. Si bien la obra de López de Velasco no se menciona ni en la versión manuscrita ni en la impresa del "Discurso de la Orthographía" de Conink, es un texto muy citado en las entradas del Diccionario (Freixas, 2010: 391).

18 Véase al respecto Conink (h. 1716: 426-443). En cambio, en la versión del discurso de los "Preliminares" del Diccionario, se ofrecen, de forma mucho más resumida, los argumentos en 
Con el fin de demostrar la inviabilidad de seguir la pronunciación como guía principal para la escritura, Conink trata con detenimiento la variación dialectal, con más ejemplos de las distintas pronunciaciones regionales que los que ofrece el "Discurso proemial"19. Como muestra, baste citar aquí la redondilla vulgar con rima en [t] que Conink aduce para ilustrar "la fuerte expression de la $t$, en los finales" en el habla "de los Valencianos y Rayanos, donde el Castellano se adapta al modo de su Dialecto": "Allá en Valencia del Cit, / Donde tienen por virtut / Saber tocar un Laut / Y haber estado en Madrit" (Conink, h. 1716: 430).

Además de insistir en la variación geolingüística, Conink subrayaba la falta de uniformidad en el habla norteña, que se manifestaba en los vulgarismos extendidos no solo "entre la gente popular", sino también "en la Corte mesma"20:

Aun entre los mesmos Castellanos hai tal qual variacion, á lo menos entre la gente popular, assi en el modo de accentuar, como en el uso de algunas palabras: pues sabemos que en la Corte mesma dicen: Espital, Perrochia, Procission, pader, probe, \&... (Conink, h. 1716: 430) ${ }^{21}$.

En el "Discurso proemial", en cambio, se recuerdan solo las variaciones en la pronunciación que afectaban a palabras con grupos consonánticos cultos que la Real Academia Española contribuyó a afianzar en el uso ${ }^{22}$ :

Aun entre los mas preciados de verdaderos y legítimos Castellanos tampoco hai igualdád en el modo de pronunciar, porque lo que unos profieren con toda expressión, diciendo Acepto, Lección, Doctrina, Propriedád, Satisfacción, Doctór: otros pronúncian con blandúra, y dicen Aceto, Leción, Letór, Dotrina, Propiedád, Satisfación, Dotór... (Real Academia Española, 1990 [1726]: LXVII-LXVIII).

De este modo, la Academia evitaba subrayar las alternancias que podrían suponer una valoración negativa de la variante castellana, presentándola de for-

contra de seguir la pronunciación como principal referente (Real Academia Española, 1990 [1726]: LXVII-LXVIII).

${ }^{19} \mathrm{La}$ existencia de dialectos es un argumento empleado ya por quienes, con anterioridad a la Academia Española, defendían una ortografía más cercana a los orígenes de las palabras que a la pronunciación (véanse Rosenblat, 1951: LVII y Cabrera, 2005: 222). Así, Gonzalo Bravo Grajera (1634) apuntaba lo siguiente: "Nuestra lengua Castellana en unas Provincias se pronuncia con mayor boato, en otras más concissamente, i sería fuera de toda razón que los naturales de cada Provincia mudassen la lengua en lo escrito, por irla mudando en lo pronunciado..." (citado en Rosenblat, 1951: LVII).

${ }^{20}$ Para la importancia del habla cortesana como modelo lingüístico, véase González Ollé (2002).

${ }^{21}$ De las variantes señaladas, solo perrochia se incluyó en el Diccionario de Autoridades, como arcaísmo y como vulgarismo en el español moderno.

${ }^{22}$ Como señala Diego Catalán (1989: 82-83), la voluntad erudita de ajustar la pronunciación a la escritura explica que "los hispano-hablantes cultivados del s. XVIII" empezaran a "pronunciar los "grupos cultos" de consonantes en los préstamos latinos (y en otros extranjerismos)", cuando lo habitual había sido elidir la consonante en posición implosiva. 
ma más neutra. La supresión de ejemplos (como la redondilla vulgar de las tierras de Valencia y los vulgarismos de Castilla) apoya la consideración de los dialectos en pie de igualdad.

Finalmente, una vez demostrado que no había un modelo único de pronunciación, Conink (h. 1716) planteaba la hipótesis de que los problemas ortográficos pudieran resolverse con la extensión de la variante castellana a toda la $\mathrm{Pe}$ nínsula Ibérica:

...demos el caso que no solo los Castellanos, sino tambien los Andaluces, Asturianos, Gallegos, y todos los demas que hablan la Lengua Castellana, se uniformen de tal modo con los Toledanos y Cortesanos, que presumen ser los mas esmerados en la propriedad, y pureza de la Lengua, y que en el concepto comun estan reputados como los Principes de ella, que todos igualmente la pronuncien sin que haya la menor diferencia en la pronunciacion de qualesquiera vocablos (Conink, h. 1716: 432-433).

Este supuesto se presentaba porque existía la opinión de que el castellano es una variante de prestigio, según sus propios hablantes — “que presumen ser los mas esmerados en la propriedad, y pureza de la Lengua" (Conink, h. 1716: 433)—y según la mayoría de los hablantes, ya que "en el concepto comun estan reputados como los Principes de ella" (ibíd.). Esta referencia a la lengua de Castilla como modelo no aparece en el "Discurso proemial", donde la hipótesis de la regularización se expone sin aludir a ninguna variante dialectal en concreto:

....aun dado el caso de que todos hablen y pronuncien de un mismo modo, y sin la menor diferéncia, no es dable que en muchissimas palabras se pronuncien tan distinta y separadamente las mismas letras de que se compónen, que se conozca por sola la pronunciación quales son, y de que modo se deben escribir (Real Academia Española, 1990 [1726]: LXVIII).

La evolución del discurso de la ortografía, cuyo texto definitivo no eleva a la categoría de modelo ni la lengua propia de un estrato ni la de una zona geográfica concreta, es acorde con la voluntad de los académicos de no ceñirse en el Diccionario de Autoridades a la representación de una única variedad dialec$\mathrm{tal}^{23}$. En las dos versiones del discurso sobre la ortografía la generalización de

\footnotetext{
${ }^{23}$ Conink, cuando se revisó la redacción final del "Prólogo" al Diccionario de Autoridades, propuso incluir los epígrafes 9 y 10 referidos a la presencia de dialectalismos en el Diccionario de Autoridades y al léxico de germanía (Blecua, 2006: 47), por lo que hay que suponer que estaría de acuerdo con la supresión de las referencias a la lengua de Castilla y de la Corte en el "Discurso proemial de la orthographía de la Lengua Castellana". Diversos estudios han destacado la presencia del léxico de distintas áreas dialectales en el Diccionario de Autoridades (véase especialmente Salvador Rosa, 1985), con un importante acopio de aragonesismos (véase Alvar Ezquerra, 1993 [1991] y Aliaga Jiménez, 1994, 1997 y 2000). Para las voces extremeñas, cfr. Montero (2006) y, para la recepción de americanismos, Seco (1988) y Cala Carvajal (2001-2002).
} 
un modelo de habla se plantea solo como contraargumento que se desestima porque imposibilitaría el respeto por los usos gráficos asentados, ya que, mediante la única guía de la pronunciación, no podrían establecerse reglas para fijar los usos de las grafías unísonas, como $\langle\mathrm{i}\rangle \sim\langle\mathrm{y}\rangle$; $\langle\mathrm{g}\rangle \sim\langle\mathrm{j}\rangle \sim\langle\mathrm{x}\rangle ;\langle\mathrm{b}\rangle \sim$ $<\mathrm{v}\rangle,\langle\mathrm{hu}\rangle \sim<\mathrm{gu}\rangle,\langle\mathrm{c}\rangle \sim<\mathrm{l}\rangle,\langle\mathrm{f}\rangle \sim\langle\mathrm{ph}\rangle,\langle\mathrm{t}\rangle \sim<\mathrm{th}\rangle$; $\langle\mathrm{c}\rangle \sim<\mathrm{k}\rangle \sim<\mathrm{ch}\rangle^{24}$. La imposibilidad de que el castellano se impusiera como modelo queda incluso demostrada porque "aun en aquellos que nacieron en el centro de Castilla no se halla igualdad, ni uniformidad en lo escrito" (Conink, h. 1716: 442).

Finalmente, el último de los aspectos en que se observan diferencias importantes entre el discurso manuscrito de Conink y el "Discurso proemial" es en la intensidad con que en el primero de los textos se compara el español con el latín y con otras lenguas romances. Ya se ha comentado que la referencia al grado de fijación alcanzado por otras lenguas forma parte de la competitividad con que se plantea el trabajo de la Academia. Por este motivo, se considera inaceptable que, procediendo todas las lenguas romances del latín, unas hayan alcanzado un grado de fijación mayor que el español:

...si es innegable, que la verdadera, y casi casi [sic] única fuente de la Lengua Española es la Latina, y que como la Toscana y la Francesa debe todo su principal ser á la que en estos Reinos estableció el absoluto, y pacífico dominio de los Romanos, continuado por mas de cinco siglos, sin haver quedado casi rastro, ni memoria del Jdioma que antes se hablaba; como no ha de ser sensibilissima la desigualdad, conque se registra (permitaseme la phrase) ajada, y afeada la hermosura de una de las mas elegantes lenguas que se conocen (Conink, h. 1716: 413-414).

Las alusiones a los sistemas gramaticales del francés y del toscano ${ }^{25}$, que contaban con una academia dedicada al estudio de la lengua, enmarcan las características del español en el contexto de las lenguas romances, distanciándolo de soluciones extremas. En este sentido debe interpretarse una afirmación como la siguiente, que supone situar al español a medio camino entre una opción gráfica más cercana a la etimología — propia del francés— y otra más apegada a la pronunciación — como el toscano-:

No porque esto lo comprehendo yo assi, me passa por la idea discurrir quanto mas pensar, que se hable de una manera, y se escriba de otra, como hacen los Franceses; y que lo escrito no deba ser, en quanto sea posible, mui conforme á lo que se pronuncia, como hace el Toscano... (Conink, h. 1716: 440).

Por lo que respecta a las lenguas clásicas, la importancia que cobra el latín en el primer tratado sobre la ortografía de la Real Academia Española se debe,

\footnotetext{
${ }^{24}$ Cfr. Conink (h. 1716: 433-434) y Real Academia Española (1990 [1726]: LXVIII).

${ }^{25}$ Para la historia de la fijación ortográfica del francés, puede consultarse Catach (2001) y, para el italiano, Serianni y Trifone (1993: 139-227).
} 
en primer lugar, a que se trata de la lengua madre, por lo que se juzga imprescindible acudir a ella para elaborar reglas de escritura. El origen latino asegura el establecimiento del alfabeto $^{26}$ y supone una guía indiscutible para la fijación ortográfica, junto con otros criterios como los usos gráficos asentados y la pronunciación.

La tesis de que "la Lengua siempre ha sido una en su origen" (Conink, h. 1716: 422) y de que siempre se han empleado "unas mesmas letras Latinas" (ibíd.) invalidaba la posibilidad de realizar cambios en el alfabeto para acercar la escritura a la pronunciación, opción rechazada por Conink (h. 1716) mediante tres argumentos: 1) la herencia latina, que ha perdurado en los usos escritos; 2) la inexistencia de uniformidad en la manera de pronunciar el español en los distintos territorios; y 3) la tradición gráfica difundida por la imprenta y por la enseñanza. Estos razonamientos parten de la defensa de conservar sin cambios el alfabeto latino, aun cuando suponga mantener "letras que no se pronuncian clara, y perceptiblemente" (Conink, h. 1716: 435) y "las que causan equivocacion por ser unisonas" (ibíd.), como las grafías para mostrar el origen foráneo de las voces ("especialmente la $y$ Griega, la $k$, la $c h$, la $t h$, y $z$ que no son latinas, y consiguientemente superfluas para la pronunciacion del Castellano”, ibíd.).

Las referencias al origen latino contribuyen a dar prestigio a la lengua vernácula al establecerse similitudes entre el proceso de fijación del español y del latín. Se comparan las variaciones que el tiempo imprime en las lenguas recordando que, tras la caída del Imperio romano, la latina se transformó "en menos de 350 años". Del mismo modo, se reconoce en la lengua castellana "notable mutacion", constatable por la dificultad de comprender algunos vocablos de textos antiguos como el "Fuero juzgo, y otros Fueros, y Escrituras antiguas" (Conink, h. 1716: 421-422).

También se recuerda el proceso de diversificación en dialectos que padeció el latín, que se equipara al sufrido por el romance en España, excepto en que, en la lengua clásica, Conink situaba la variación únicamente en la lengua oral:

La lengua Latina es constante que no se pronunciaba, ni hablaba en las Provincias sugetas al Imperio Romano con aquella igualdad, perfeccion, y hermosura, que en Roma, y aun entre sus naturales, y moradores no todos la posseian, y hablaban con la pureza, y elegancia de Julio César, Ciceron, Caton, y otros de esta clase; pero todos la escribian de una mesma manera, sin discrepar los unos de los otros, y por esso su methodo sirvió de regla para fijar en todo el mundo el modo de escribirla (Conink, h. 1716: 442-443).

El modelo de la lengua escrita latina residía en la emulación de las auctoritas, los autores de prestigio en cuyo conocimiento se basaba el estudio

\footnotetext{
${ }^{26}$ Véase Santiago Alcoba (2012) para la evolución de las letras que conforman el alfabeto en los Diccionarios de la Real Academia Española.
} 
de la gramática. Del mismo modo, la Academia Española, en su primer Diccionario, se basa en las autoridades para mostrar los usos más reputados. No obstante, para la ortografía, como explica Conink en la versión más temprana de su discurso (y como ya se ha comentado), no se encuentran textos que presenten un uso homogéneo, por lo que es preciso que el criterio de autoridad se combine con la etimología y la pronunciación.

La perplejidad ante los usos gráficos divergentes documentados en las autoridades, la condena de la pronunciación como única guía para fijar la ortografía y la voluntad de acercarse al latín son ideas fundamentales del discurso de Conink (h. 1716) que, como Alcázar (1715), también realizaba propuestas de reglas para delimitar los usos de las letras. En el apartado siguiente, analizaré el proceso de redacción de normas ortográficas, tomando en consideración los discursos de Alcázar (1715) y de Conink (h. 1716), el "Discurso proemial de la orthographía" (1726) y las discusiones que reflejan las Actas sobre el uso de determinadas grafías.

\section{El ESTABLECIMIENTO DE REGLAS ORTOGRÁFICAS}

En los discursos de Alcázar (1715) y de Conink (h. 1716) se encuentra una versión incipiente de una serie de reglas para fijar el uso de letras unísonas. Alcázar reflexionó sobre $\langle\mathrm{z}>\mathrm{y}\langle\mathrm{c}\rangle \mathrm{y}<\mathrm{b}\rangle \mathrm{y}\langle\mathrm{v}\rangle$; y Conink diferenció el empleo de: $\langle\mathrm{i}\rangle$ y de $\langle\mathrm{u}\rangle$ con valor vocálico y consonántico; $\langle\mathrm{i}\rangle,\langle\mathrm{j}\rangle$ e $\langle\mathrm{y}\rangle$; $\langle\mathrm{u}\rangle$ y $<\mathrm{v}>$; $<$ b $>$ y $<\mathrm{v}>$; $<$ ç $>$ y $<\mathrm{z}>$; $<\mathrm{j}>,<\mathrm{x}>$ y $<$ ge, gi $>$; y $<\mathrm{q}>$ y $<\mathrm{c}>$. A estas letras, en el "Discurso proemial" (§ IV, "De las letras unísonas, ò que se equivocan en la pronunciación"), se añadió la distinción de $<\mathrm{g}>$ y de $<\mathrm{h}>$ delante de $<$ ue $>27$.

Las reglas ortográficas se basan en la etimología, en los usos gráficos y en la pronunciación. Las diferencias entre las primeras propuestas de Alcázar y de Conink y las normas ortográficas del Diccionario estriban en que estas últimas constituyen una versión más acabada, en la que se reducen los ejemplos y se ofrecen como definitivas algunas soluciones que, en un principio, se apuntaban en contraste con usos existentes.

A continuación se examinará el desarrollo de las reglas propuestas para las grafías unísonas en los discursos manuscritos de Alcázar y de Conink y en el apartado IV del "Discurso proemial de la orthographía" (1726). Para este análi-

${ }^{27}$ En el tratado ortográfico del Diccionario de Autoridades, se incluyeron los apartados $\S \mathrm{V}$ sobre "el uso de la duplicación de las letras"; § VI, "de la concurréncia de diversas consonantes", acerca de los grupos cultos; y § VII, "del modo de dividir las palabras al fin del renglón, y de las sylabas compuestas de dos vocáles", que se ocupa de las reglas de silabificación y de los diptongos. 
sis, se tendrán en cuenta también los acuerdos en materia ortográfica que se recogen en las Actas de la Real Academia Española durante la redacción del Diccionario de Autoridades (1713-1739) ${ }^{28}$.

\section{1. $\langle i>\sim\langle j\rangle \sim\langle y\rangle y\langle u\rangle \sim<v>$ con valores vocálicos y consonánticos}

Hacia 1716, Conink delimitó los usos vocálicos y consonánticos de $<\mathrm{i}, \mathrm{j}, \mathrm{y}\rangle$ $\mathrm{y}<\mathrm{u}, \mathrm{v}>$. Se basaba en las convenciones de "los modernos", quienes

para evitar la duda de quando son vocales, y quando consonantes, han discurrido (á lo menos para el uso de la Lengua Latina) formar dos diferencias asi en la $\mathrm{i}$ como en la $\mathrm{u}$, fijando para el uso, y distintivo de las vocales la i pequeña sin rabillo, y la u abierta; y para quando son consonantes, la j larga, y la v que llaman de corazoncillo (Conink, h. 1716: 445-446).

La distinción entre $<\mathrm{u}>\mathrm{y}<\mathrm{v}>$ aún representaba un problema cuando en 1721 Pedro de Acevedo, encargado de la combinación Au del Diccionario de Autoridades, "dudaba si separar las voces en las que $u$ era vocal de aquellas en que se utilizaba como consonante" (Martínez Alcalde, 2007: 112; Lázaro Carreter, 2000 [1972]: 120; Actas, 24-VII-1721). Esta dificultad se resolvió mediante un acuerdo que, como en Conink h. 1716, reservaba el uso de $<$ u para la vocal y de $<$ v $>$ para la consonante:

...pareció que estas letras se deben mirar como distintas, mayormente cuando para la mayor claridad de la escritura es ya práctica de la Academia valerse con distinción de los dos caracteres que para esta letra están puestos en el abecedario castellano de la Cartilla, por donde todos aprendimos a leer, usando de la $u$ ordinaria o larga, como llaman los Impresores, para expresar la $u$ vocal y de la corazón para la consonante (Actas, 24-VII-1721).

En el "Discurso proemial" se mantuvo la distribución de $<\mathrm{i}\rangle,\langle\mathrm{y}\rangle,\langle\mathrm{u}\rangle \mathrm{y}$ $<\mathrm{v}>$ propuesta por Conink (h. 1716), aunque se eliminaron las referencias a $<j>$, cuyo uso para representar a la consonante palatal ya se consideraba poco recomendable en el texto escrito por Conink hacia 1716:

en Castellano la j consonante Latina, corresponde en lo figurado a la j, Castellana; y si esta se escribiesse como j consonante, en lugar de hacer clara la escritura, la pusiera mucho mas sencilla [sic], y equívoca (Conink, h. 1716: 447) ${ }^{29}$.

\footnotetext{
${ }^{28}$ En futuros estudios sobre la aplicación de las normas ortográficas en el Diccionario de Autoridades se examinarán con detalle las entradas de esta obra, análisis que sobrepasa el propósito de la presente contribución. Este examen se verá beneficiado por las posibilidades de obtención de datos que ofrece la magnífica edición electrónica del primer diccionario académico (Real Academia Española, 2013 [1726-1739]).

${ }^{29}$ También en la entrada para la letra $<\mathrm{i}>$ del Diccionario se delimitaron los usos de $<\mathrm{i}, \mathrm{j}, \mathrm{y}>$ según las directrices señaladas por Conink (véase Diccionario de Autoridades, s. v. I).
} 
Como en el discurso de Conink hacia 1716, el "Discurso proemial" no consideraba problemático que $<y>$ se empleara no solo para la consonante palatal fricativa del castellano, sino también para representar la vocal /i/ en palabras de origen griego, "y se escriba Symbolo, Mysterio, Martyr, Azymo, \&c." (Real Academia Española, 1990 [1726]: LXXI, § IV.28), pues en estos casos quedaba claro su valor vocálico por no encontrarse nunca encabezando una sílaba ${ }^{30}$.

\section{2. $\langle b>\sim<v>$}

Desde el texto de Alcázar, para distinguir los usos de $\langle\mathrm{b}\rangle$ y de $<\mathrm{v}\rangle$, se estableció, como principio básico el seguimiento de la etimología (véase $\S 2$ ). Tanto Alcázar como Conink consideraban que la pronunciación unísona de ambas grafías era la causa de su frecuente confusión en la escritura.

En los discursos de Conink, el hecho de que "los Españoles [...] no hacemos distinción en la pronunciación de estas dos letras" (Real Academia Española, 1990 [1726]: LXXII) no se presentaba ya como un "abuso" (Alcázar, 1715: 119), sino como una característica de nuestra lengua. Conink subrayaba, no obstante, la necesidad de no trasladar esta confusión a la ortografía, porque podría dar "sobrado motivo á las naciones extranjeras para que nos tengan por bárbaros” (Conink, h. 1716: 451).

El establecimiento, desde el texto de Alcázar, de una norma para $\langle\mathrm{b}\rangle \mathrm{y}$ para $<v>$ basada en la "legítima Orthographía de los orígenes de las voces" (Alcázar, 1715: 120) supuso que, en la práctica, no siempre se respetara el criterio establecido en la versión impresa de la Planta (1713), según el cual debían recogerse en el Diccionario las formas con grafías no etimológicas que tuvieran un uso extendido. De este modo, Alcázar consideraba innecesaria "la regla que acerca de este punto y con ocasión de la palabra Volber [sic] nos da la Planta y Método aprouado por nuestra Academia” (Alcázar, 1715: 120).

En la primera versión de la Planta (transcrita en las Actas del 2-XII-1713) se establecía únicamente un criterio etimológico para el tratamiento de las variantes de la palabra volver, ya que la Academia se propuso:

Annotar las variedades que se hallaren en el escribir algunas Voces, aprobando la mejor, y desechando las demás: como algunos dicen aóra, otros agóra, y paréce lo mejor decir ahóra, advirtiéndolo en los lugáres que les tocáre. Lo mismo se dice del Verbo Volver, que muchas Personas, y todos, ò casi

\footnotetext{
${ }^{30}$ Cfr. la entrada para la letra $<y>$ del Diccionario de Autoridades: "VIGESIMA quarta letra de nuestro Alphabéto, tomada de el de los Griegos, en el qual se llama Ypsilon, y los Latinos la usaron como letra vocal en las palabras tomadas del Griego: y nosotros seguimos lo mismo: como en Tyrano, Mysterio".
} 
todos los Impressóres le comienzan con B, desfigurandole su origen (Actas, 2-XII-1713).

Se incluyó, en cambio, en la edición de la Planta de 1713, una adición a esta regla según la cual debían incluirse los usos gráficos generalizados, como el de bolver, con remisión a las formas etimológicas propuestas por la Real Academia en su Diccionario:

Mas juntamente (atendiendo à excusar la confusión en los Lectóres del Diccionario, que ignoraren de donde las Voces se origínan, y las huvieren de buscar) se annotarán según el uso común, ò vulgar de escribirlas, en el lugar que les tocáre del Alphabéto; pero remitiéndolas para su explicación al que deben tener segun su orígen y Etimología: y assi el exemplo puesto arriba de Volver, se colocarà en la $\mathrm{B}$, por atender al uso común, diciendo: Bolver. Véase Volver (Real Academia Española, 2010 [1713-1726]: 451).

Esta norma - fruto de una enmienda realizada al aprobarse el texto de la Planta, el 2-XII-1713 (Actas y Freixas, 2010: 451, n. 94) - se mantuvo en la reimpresión de la Planta en los Preliminares del Diccionario de Autoridades (Real Academia Española, 1990 [1726-1739]: I, p. XVI). No obstante, y seguramente debido a la observación de Alcázar, no se incluyó en el Diccionario el lema bolver, de uso común en la época ${ }^{31}$, sino solo una entrada para la forma etimológica ${ }^{32}$.

En la práctica lexicográfica, sin embargo, hay casos en que los académicos optaron por incluir como lemas variantes documentadas, siguiendo el criterio de la Planta y contraviniendo la propuesta de Alcázar. Esto ocurre especialmente en el primer volumen del Diccionario, cuando aún se estaba estableciendo el método lexicográfico, donde se introducen como lemas formas como ahuelo, la abuelo, la (con remisión a avuelo, la) agüelo (con remisión a avuelo) avuelo, $l a^{33}$.

De todas formas, como se reconoce en el discurso manuscrito de Conink, el respeto por una grafía cercana a los orígenes de las palabras no resultaba un criterio de fácil aplicación cuando se desconocía el étimo:

Yo no dudo que en algunas palabras es dificultoso discernir si se deben escribir con $b$, ó con $v$, respecto de que, ó no ó no [sic] está claro, ó se ignora su raíz, como bala, baiben, bola, bermejo, embeleco, embidar, y assi otras

${ }^{31}$ Véase la información al respecto de Joan Coromines y José Antonio Pascual (2012 [19801991]: s. v. volver).

32 Para el tratamiento de bolver volver en el Diccionario de Autoridades, véase Freixas (2010: 171-172 y 451).

33 Véase también en $\S 4.3$ el tratamiento de las variantes buces; buzes; bruzes, ò bruzas en el Diccionario de Autoridades. Francisco M. Carriscondo Esquivel (2009: 126-127) recoge el acuerdo tomado por la Academia Española en relación a las variantes ortográficas en 1731. 
semejantes, que se hallan escritas con $u$ repetidas veces en los Autores; para cuya decision, y establecimiento, está el Supremo Tribunal de la Real Academia (Conink, h. 1716: 451-452).

En este párrafo, eliminado en el "Discurso proemial", se mencionan voces cuya grafía se resolvió en el Diccionario en función de la etimología. Así, se fijó como lema principal vaivén, según la etimología propuesta ("Dixose de las voces Va, y Viene, porque sucede assi este movimiento" "34, Diccionario de Autoridades, s. v. vaivén), y baibén ${ }^{35}$ se incluyó solo como una forma con remisión a vaivén. Del mismo modo, se prefirió envidar a embidar ${ }^{36}$, forma de uso frecuente en los textos clásicos, pero desestimada por relacionarse la palabra con el latín invitare ("Viene del latino Invitare, por cuya razon no se debe escribir con $b$, sino con v", Diccionario de Autoridades, s. v. envidar).

En ocasiones, la etimología fijada en el Diccionario de Autoridades supuso incluso consolidar grafías que, en realidad, apartaban las voces de sus verdaderos orígenes. Así ocurrió con berza ${ }^{37}$. La lectura de una disertación de Antonio Dongo sobre la procedencia de esta palabra (Actas, 12-XII-1720) provocó que se la relacionara erróneamente con BRASSICA y no con verde (Lázaro Carreter, 2000 [1972]: 122).

Para otros casos dudosos, de palabras de origen incierto, se acabó adoptando un criterio adicional, que no aparece en la versión manuscrita del "Discurso de la Orthographía", pero sí en el texto de los Preliminares del Diccionario. Se trata de considerar la $<\mathrm{b}>$ como grafía preferible por ser la "más genial de la nación” (Actas, 30-IV-1722). Este principio es el que determinó, por ejemplo, la grafía de balumba:

Disputose si la palabra Balumba se debe escribir con $B$, como la traía puesta el sr. d. Pedro de Acevedo siguiendo a Covarrubias que la da la etimología de Ballo griego, o si se debía remitir a la $V$, considerando venir de la voz

\footnotetext{
${ }^{34}$ Cfr. la etimología de vaivén según Coromines y Pascual (2012 [1980-1991]: s. v. ir): "no parece tratarse de los imperativos, sino de los indicativos de ir y venir, pero entonces no se comprende la forma del último; quizá sea palabra de procedencia forastera, comp. fr. va-et-vient (que parece ser moderno) y cat. vaivé íd.”.

${ }^{35}$ Con anterioridad al Diccionario de Autoridades, baiben, bayben, baiven y bayven se documentan en el Corpus del Nuevo Diccionario Histórico del Español, de la Real Academia Española y la Fundación Lapesa (Instituto de Investigación Rafael Lapesa de la Real Academia Española, 2013).

${ }^{36}$ El Diccionario crítico etimológico castellano e hispánico, de Coromines y Pascual (2012 [1980-1991]) atestigua que la forma con emb-, documentada ya en 1570, fue "frecuente en los clásicos" (véase envidar, s. v. invitar). Acorde con la etimología propuesta en el Diccionario de Autoridades, señala que envidar es "duplicado hereditario de invitare" (véase envidar, s. v. invitar).

${ }^{37}$ Cfr. el caso de viga, que Coromines y Pascual (2012 [1980-1991]: s. v. viga) relacionan con el lat. BÎGA y los académicos, siguiendo a Covarrubias, con vigor (Actas, 23-X-1721 y Diccionario de Autoridades, s. v.).
} 
Volumen $^{38}$; y habiéndose pasado a votar, se determinó por la mayor parte de votos que en la letra $B$, respecto de que no habiendo total certidumbre de el origen, parece se debe preferir esta letra como más genial de la nación, a que se agrega la autoridad de Covarrubias y el estilo común de hallarse siempre o casi siempre escrita esta voz con $B$ (Actas, 30-IV-1722).

En el "Discurso proemial" esta norma se establece de este modo:

Lo quarto siempre se debe usar de la $B$ quando no se sabe ciertamente, ò se duda del orígen de las dicciones, porque es mas connaturál à nuestra manéra de hablar la pronunciación de la $B$, que de la $V$ (Real Academia Española, 1990 [1726-1739]: LXXII).

La historia de balumba muestra cómo el tratado de ortografía inicialmente propuesto por Adrián Conink se fue enriqueciendo con las decisiones que se fueron tomando en el proceso de redacción y de revisión de las entradas del Diccionario. Las Actas también confirman el afán de los académicos por tratar de respetar la norma establecida para fijar los usos de $\langle$ b $>$ y de $\langle$ v $\rangle$. Así lo reflejan los casos en que se determinó adecuar la ortografía de las palabras a la etimología propuesta por los académicos. Por ejemplo,

...se decidió que alverja debía escribirse con $v$. Atendiendo a que, según cualquiera de las etimologías que parece le convienen le toca la $V$, se acordó se escriba con ella, sin embargo de hallarse regularmente escrita con $B$ ( $A c$ tas, 26-IX-1720).

Junto al criterio etimológico, las Actas dejan constancia de cómo también fue preciso tener en cuenta el uso más común en las autoridades. Así, para bravo —que mereció un estudio especial por Jerónimo Pardo, quien defendió "ser más consecuente dar a esta voz el origen español que los que muchos le aplican del griego o latino" (Actas, 17-X-1720)_, se optó por la escritura con <v> en la segunda sílaba, por documentarse así entre los "Autores y Diccionarios":

La etymología de esta voz siente Covarr. que viene del nombre Griego Brabeion; pero no paréce correspondiente al significado de la palabra Bravo, que es mui antigua Española, y se halla escrita regularmente con $v$ en la segunda sylaba, en Autores y Diccionarios (Diccionario de Autoridades, s. v. bravo).

En ocasiones, el criterio del uso extendido se impuso incluso a la etimología, como en barrer, con $\langle\mathrm{b}\rangle$, ya que, a pesar de que se le atribuía la etimolo-

\footnotetext{
${ }^{38}$ Cfr. Diccionario de Autoridades, s. v. balumba: "Covarr. dice que es voz barbara, aunque trahe la etymología del verbo Griego Ballo, que significa amontonar. Otros la deducen del Hebréo Balúl, que significa cosa mezclada sin orden”. Joan Coromines y José Antonio Pascual (2012 [1980-1991] s. v. balumba) aclaran que es un préstamo, "tomado del cat. volum 'volumen' (también cat. balum, embalum, abalum 'balumba'); y éste del lat. VOLÛMEN íd.".
} 
gía latina Verro, "en el uso común de los autores y diccionarios se halla con B" (Actas, 24-V-1725) $)^{39}$.

\section{3. $\langle c ̧>\sim<z>$}

Tras demostrar la pertinencia de considerar $<\mathrm{z}>$ como la última letra del alfabeto, Alcázar se planteó su uso con relación a $<$ ç $>$ y a $<$ s $>$. El discurso de Alcázar supuso un primer paso hacia la supresión de $<c ̧>$ que se produjo en el Diccionario de Autoridades, donde se consideró que "realmente se puede reputar por supérflua la ç" (Real Academia Española, 1990 [1726]: LXXIII). Alcázar solo admitía un uso restringido de <ç> en posición inicial de sílaba en el interior de las palabras (donde alternaba con $<\mathrm{z}>$ ), pues, en el resto de colocaciones, señalaba que debía emplearse $<\mathrm{z}>$, ya sea al "principio de diczión" (Alcázar, 1715: 115), ya sea en posición final de palabra o de sílaba. En posición final, prefería el uso de $<\mathrm{z}>$ y desestimaba su sustitución por $<$ ç $>$ o por $<\mathrm{s}>$, por el respeto a la tradición gráfica consolidada. En estos casos, si:

se intentase substituir por la $Z$ en lo escrito, la $C$ o la $S$, sería introduzir en nuestra escriptura castellana una no Orthographía, sino Heterographía estravagante y jamás acostumbrada, motivo por el qual la calificaría yo (a mi corto juizio sin temeridad) de bastarda y aun de bárbara, como se puede ver en los exemplos que se siguen.

Por Mayorazgo, Mayoraçgo, Mayorasgo, \&.

Por piezgo, pieçgo, piesgo, \&... (Alcázar, 1715: 116).

Mediante la transcripción de palabras con grafías no habituales, con $<$ ç $>$ y con $<\mathrm{s}>$, Alcázar sorprendía al lector con un criterio estético, ya que pretendía que rechazara, por inusual, la imagen de las voces con grafías distintas a $<\mathrm{z}>$. Al criterio icónico, se sumaba el intento por representar la pronunciación de las palabras, ya que Alcázar resolvía la posible alternancia entre $<\mathrm{z}>$ y $<$ s $>$ en posición final de palabra ( $<$ ç $>$ quedaba descartada para este uso) señalando la diferencia existente en su realización:

También sería disonante a la pronunciación castellana la substitución de la $S$ por la $Z$ en el fin de dicziones, pues abríamos de dezir Andalus por Andaluz y Andaluses por Andaluzes (Alcázar, 1715: 118).

\footnotetext{
${ }^{39}$ Cfr. Diccionario de Autoridades, s. v. barrer: "Viene del Lat. Verrere: y aunque segun este origen se debía escribir con $v$, respecto de que el uso común está en contrário, y que lo escriben con $b$ Covarr. Nebrixa, Salas, Calepino, y otros Diccionarios se pone con la b". Joan Coromines y José Antonio Pascual (2012 [1980-1991]: s. v. barrer) confirman la etimología, del latín VERRRE y que "la $b$ - ya es general en el castellano medieval (Berceo, Nebr., etc.)".
} 
Demostraba con ello partir de un modelo de lengua cercano al habla norteña, con dos realizaciones sibilantes distintas para $<\mathrm{z}>$ y para $<$ s $>$. En tensión con la tradición gráfica, se encontraba el criterio de la analogía en el que se basaba para defender el mantenimiento de la $<\mathrm{z}>$ en las palabras con flexión de número:

...otra buena regla orthographia [...] es que los derivados deven conservar las consonantes de sus raízes, o inconbeniente en lo contrario. Quiero decir, que así, como si se escriviera Andalus en singular se havía de escrivir en el prurar [sic] de Andaluses, así por que se escrive Andaluz, se deve escrivir Andaluzes, aunque tengan la pronunciación homogénea. Y por lo mismo de la palabra Relox devemos derivar Reloxes y no Reloges ni Relojes, siendo la razón potíssima de esta regla, ser devido mantener en los derivados y no desfigurarles el origen de sus primitivos (Alcázar, 1715: 118-119).

Se demuestra aquí la voluntad de adoptar una norma general para mantener la consonante final de la raíz en las palabras flexionadas. Alcázar deseaba imponer este criterio a la tradición gráfica, en la que era y sigue siendo común $<\mathrm{c}>$ ante $<\mathrm{e}, \mathrm{i}>$.

Junto al texto de Alcázar, la versión manuscrita del "Discurso de la Orthographía" es fundamental para comprender la decisión final de la Academia Española de prescindir del uso de $<c ̧>$ en el Diccionario de Autoridades. En este texto, Conink (h. 1716: 455-467) repasó de forma detenida las opiniones de tratadistas anteriores sobre los usos de $<c ̧>$ y de $<\mathrm{z}>$. Tras ello, expuso las razones por las que desaconsejaba el uso de $\langle c ̧>$, observaciones que solo en parte se recogen en el "Discurso proemial" y que son especialmente interesantes para comprender mejor los principios ortográficos de la Academia Española. Declaraba estar de acuerdo con los que consideraban que "la $c ̧$ y la $z$. no son dos letras distintas, sino una diversamente formada" (Conink, h. 1716: 468), cuya distinción no merecía la pena conservar por varios motivos: los "Autores más clasicos" utilizaban indistintamente una u otra grafías y se trataba de letras formalmente muy similares que, en la época, no representaban sonidos distintos:

Las consideraciones que me inducen á este pensamiento, son: la primera, que los Autores mas clásicos, que han escrito tocante al origen, y uso del Lenguage Castellano, quales son el Dr. Bernardo de Alderete y D. Sebastian de Covarrrubias, ó no las distinguen claramente, ó las confunden de tal suerte, que sin dar razon de su diversidad se valen promiscuamente de ambas en unos mesmos vocablos, en unos mesmos libros, y capítulos. La segunda, que haviendo hecho particular reflexion sobre la figura, y formacion de la $c$, y cotejándola con la $z$ Griega menor (porque la mayúscula es casi la mesma que la Latina) he hallado que son entre si mui parecidas; y considerando por otra parte, que en el modo comun y natural, conque regularmente se pronuncian la $c$ y la $z$, apenas el mas preciado de crítico, y escrupuloso las puede dintinguir; confiesso que no descubro fundamento sólido que obligue á sentir 
que son dos letras essencialmente diversas, con distintos usos, y de tan diferente pronunciacion, que la una no se parezca á la otra, ni tenga que ver con ella (Conink, h. 1716: 468-469).

Esta misma opinión, sin las alusiones a Bernardo de Aldrete y a Sebastián de Covarrubias se halla resumida en el Diccionario de Autoridades (Real Academia Española, 1990 [1726]: LXXIII) ${ }^{40}$. De manera conciliadora con los reacios a este nuevo uso, se apuntaba la posibilidad de establecer el empleo de <ç> y de $<\mathrm{z}>$ en distribución complementaria, con el fin de que se diferenciasen

sus usos separados (qual es usar de la ç en medio de las palabras todas las veces que precede consonante, como en Bonança, Esperança, Fuerça, Ensalçar, Dulçura, Confiança, y de la $z$ siempre que precede vocál, y en el princípio de las dicciones, como Razón, Pureza, Riqueza, Gozo, Zelo, Zapato, Zumba, Zorra (Real Academia Española, 1990 [1726]: LXXIII).

Esta convención, no secundada en el Diccionario de Autoridades, también se señalaba en el texto manuscrito de Conink, donde se afirmaba que este uso se había podido comprobar "entre otros Autores" en los escritos de Ambrosio de Morales "y especificamente en su erudito, y eloqüente discurso de la Lengua Castellana, que precede á las obras de su tio el Maestro Oliva" (Conink, h. 1716: 470$)^{41}$. Otra posible distribución de $<c ̧>$ y de $<\mathrm{z}>$, ligada a la etimología de las voces, se expone solo en la versión manuscrita del discurso de Conink, y se rebate en este texto por la dificultad que suponía, pues se trata de

otra mas intrincada y dudosa regla, qual es la de recurrir á averiguar las raíces de las voces; quëstion tan falible como interminable, y sugeta muhas veces al arbitrio de una mera conjetura (Conink, h. 1716: 474) (2) $^{2}$

Esta apreciación no constituye un ataque al empleo de la etimología para regular la ortografía, sino el reconocimiento, ya expuesto en otros lugares del Diccionario de Autoridades, y especialmente en el "Discurso sobre las etimologías", de la imposibilidad de recurrir siempre a los orígenes de las voces, ya

${ }^{40}$ Cfr. las observaciones sobre la $<c ̧>$ que se encuentran en el Diccionario de Autoridades, en el artículo dedicado a la letra $<\mathrm{c}>$.

${ }^{41}$ El Discurso sobre la lengua castellana de Ambrosio de Morales, publicado como prólogo a las obras de su tío Fernán Pérez de Oliva (1586) constituye no solo un modelo de usos gráficos, pues Conink se apoya en él para proponer una norma de distribución de $<c ̧>$ y de $<\mathrm{z}>$, sino que es también es un referente ideológico para el académico. Así, el ideario expuesto en la defensa de la lengua realizada por Morales (véase al respecto Ruiz Pérez, 1993: 357-378) se evoca con elogios en el colofón de la versión manuscrita del "Discurso de la Orthographía". Para todo ello, véase, más adelante, $§ 5$.

${ }^{42}$ La Real Academia Española se propuso averiguar la etimología de las voces remontándose solo a la lengua madre, el latín (Jiménez Ríos, 2008: 301-309). Se asumió, con ello, que el Diccionario no sería exhaustivo en el acopio de etimologías. 
sea por ser en algunos casos desconocidos, ya sea por contravenir un uso más extendido:

... muchas Voces han nacido tan legítimas del absoluto imperio, ò tiranía del uso, que es imposible hallarlas raíz, por no conocer otra madre, que el gusto, y uso de los hombres: y assi en estas es forzoso que ceda el discurso à la razón, sin empeñarse en descubrir raíz [...], porque es cierto que muchas Voces no la tienen" (Real Academia Española, 1990 [1726-1739]: "Discurso proemial sobre las etymologías", p. LX).

La supresión de $<c ̧>$ en el Diccionario de Autoridades ${ }^{43}$ y su sustitución por $\langle\mathrm{z}\rangle^{44}$ fue fruto de reflexiones maduradas, como lo demuestran las extensas observaciones sobre el uso de esta letra en los discursos manuscritos de Alcázar y de Conink y el hecho de que, en las primeras versiones de los artículos del primer volumen del Diccionario de Autoridades, aún se empleara la $<c ̧>$. Tal y como se refiere en las Actas, el 25 de julio de 1720 se decidió establecer los usos de $<c ̧>$ y de $<\mathrm{z}>$ según la distribución observada en autores como Ambrosio de Morales. El acuerdo surgió al revisar la combinación $A z$, encargada a González de Barcia y reelaborada por Conink, y en las Actas se relata así:

Siendo el motivo principal que ha tenido el sr. d. Adrián para trabajar este papel la duda que se le ofrecía sobre el uso de la $Z$ y la $C$ —que es una de las cosas en que se halla mayor variedad en el modo de escribir-, y que para poder poner corriente la combinación de la $Z$ que estuvo a cargo del sr. d. Andrés González de Barcia para el Diccionario, y últimamente de orden de la Academia, ha reducido el mismo sr. d. Adrián al método de la Planta, y que llegaba el caso de comenzar a leerse en esta Junta, se trató desde luego de este punto y se resolvió seguir el medio que propone en dicho papel, que es el de usar de la $Z$ siempre que estuviere entre dos vocales, como azagaya, destroza, etc. y de la Ç después de consonante, como en Arçón, trença, \&., como lo han usado varios autores de buena nota y con especialidad Ambrosio de Morales, y que en consecuencia desto todas las voces que estaban puestas en la $A C ̧$ se remitan y reduzcan a la $A Z$ porque en esta combinación nunca está después de letra consonante (Actas, 25-VII-1720).

\footnotetext{
${ }^{43}$ Cfr. la entrada para zedilla donde se explica la exclusión de <ç> del abecedario: "La letra antigua nuestra, que se formaba de una $c$, y de una virgulilla, ù tilde unido debaxo (como esta ç) cuya pronunciacion era la misma, que la de la $z$, aunque segun algunos con mayor suavidad, la que por imperceptible, y demás razones, que se exponen en el discurso Proemial, se ha excluído de nuestro Alphabéto, como no necessaria”.

${ }^{44}$ Cfr. la entrada para $<\mathrm{z}>$ en el Diccionario de Autoridades: "ULTIMA letra de nuestro Alphabéto, añadida à él, tomandola del Griego, para conservar sus etymologías, y las Arabes, y se ha substituído tambien en lugar de la cedilla antigua Española, por ser la misma la pronunciación, y por las demás razones, que se dicen en el discurso Proemial de la Orthographía de este Diccionario".
} 
Este criterio no se aplicó en el Diccionario de Autoridades —aunque, como se ha señalado, se incluyera como posibilidad en el "Discurso proemial"-, ya que se prefirió optar por una ortografía más cercana a los modelos de escritura clásicos, donde la $<c ̧>$, invención española, constituía una anomalía en el alfabeto de raigambre latina.

En la misma línea de relación con los modelos latinos, se encuentra el acuerdo - presente en los dos textos de Conink - de mantener el uso de $<\mathrm{c}>+<$ e $>$ en los plurales de palabras con $<\mathrm{z}>$ final, en contra de la opción defendida por Alcázar:

aunque no es dudable, que es buena regla de Orthographia la de que los derivados conserven la raiz de sus primitivos; esta se debe entender, y guardar en aquellos derivados, en quienes se considerare razon evidente para que la retengan, como relox, box, balax, y otras, que se deben escribir con $x$ y no con $g$, ó $j$, diciendo: reloxes, boxes, balaxes; pero no donde se encontrare inconveniente (como advierte el Rmo. P. Alcazar en su citado parecer) y no pudiendo en mi corto juicio ser mayor, ni mas reparable, que el de trastocar, y desfigurar sin necessidad el origen Latino; carece de fundamento pretender conservar la $z$, y escribir pazes, vezes, felizes, vozes, luzes, quando el Latino escribe con $c$ : paces, vices [sic], felices, voces, luces (Conink, h. 1716: 475-476).

La propuesta de Alcázar, desestimada por la Academia, representaba, no obstante, un uso posible en la época, como lo demuestra que en el Diccionario de Autoridades se documenten plurales en -zes en las definiciones (donde ocasionalmente se encuentran formas como cozes, raízes, vezes y vozes ${ }^{45}$ ) y en las citas de las autoridades. En este sentido, un caso paradigmático lo constituye buzes, que se incluye como lema del Diccionario, del mismo modo que buces y bruces, ò bruzas, formas documentadas en La hora de todos y la Fortuna con seso (h. 1635), de Francisco de Quevedo, uno de los autores más apreciados y citados en el Diccionario de Autoridades ${ }^{46}$.

\section{4. $\langle j\rangle \sim<x>\sim<g e$, gi $>$}

El establecimiento de los usos de $<\mathrm{j}>$ y de $<\mathrm{x}>$ fue también muy laborioso. El propio Adrián Conink recogía en el "Discurso de la Orthographía" (Conink,

\footnotetext{
45 Por su escasa presencia, las voces en -zes en las definiciones y descripciones parecen ser descuidos en la unificación gráfica. La edición electrónica del Diccionario de Autoridades (Real Academia Española, 2013 [1726-1739]) permite comprobar que cozes se documenta en la definición de falso; raízes, en la de cepa y césped; vozes, en la de caña; y vezes, en cantar, capital, castigadísimo, cierto y largo. En las definiciones y autoridades del Diccionario apenas se documentan siete entradas con la forma vezes y 2.027 con la forma veces.

${ }^{46}$ Véase una valoración de la presencia de Quevedo en el Diccionario de Autoridades en Freixas (2003: 411-415), Candelas Colodrón (2004), Álvarez de Miranda (2004: 389-416) y Freixas (2010: 288).
} 
h. 1716: 478) las consideraciones que realizó "con el motivo de la duda que se ofreció sobre si el verbo dexar se debia escribir con $j$, ó con $x$ ". Esta alusión, que se omitió en el "Discurso proemial de la orthographía de la Lengua Castellana", se refiere a la propuesta de Conink en la junta del 16 de julio de 1716. Según las Actas:

Con el motivo de traer puesto el dicho sr. don Juan de Villademoros el verbo dexar con $J$ en lugar de la $x$, en la suposición de que todos los vocablos que en su origen latino no tienen expresa la $x$ deben ser con $J$ en castellano, propuso el sr. d. Adrián Conink convendría se hiciese reflexión sobre esta materia, teniéndose presente la doctrina del D. Bernardo Aldrete en los capítulos 11 y 12 del libro segundo del Origen de la lengua castellana, donde trata largamente de la mudanza de unas letras en otras, y establece que la $s$ latina es de otra lengua, las dos ss y la gs siempre que se convierten es en $x$, y no en J, como de Capsa, Caxa, de Roseus, Roxo, de Sapone, Xabón. Y las que en origen tienen $C, G, L, I$ la mudan en $J$, como jaula de cavea, jardín, de giardino, hijo de filius, juez de judex, todo lo cual es conforme al uso común de los autores; con que el verbo dexar se debe excribir con $x$, por venir del latino desino. Y habiéndose discurrido sobre ellos se determinó deberse seguir esta regla y que en su consecuencia todas las voces que tuviesen en el origen la $s$, u otras de las letras que no deben convertirse en $J$, aunque en castellano tengan la pronunciación de ella, se escriban con $x$, y aquellas que en el origen tienen las $C, G, L, I$ se escriban con $J$ (Actas, 16-VII-1716).

Así pues, la Corporación optó por mantener $<\mathrm{x}>$ para las palabras procedentes de [s] latina. En el discurso manuscrito de Conink, como en la propuesta que recogen las Actas, este uso se explica según el principio etimológico de Bernardo José de Aldrete:

...si las palabras en sus origenes tienen $s$, en este caso se debe usar de $x$ porque la $s$ tiene el sonido mui conforme al de la $x$; y por esta razon (dice el Doctor Alderete) $(*)$ [margen derecho: $(*)$ Lib. $2 .^{\circ}$ del origen de la Lengua Castellana] que los Españoles antiguos la mudaron en $x$, y pronunciaron $\mathrm{y}$ escribieron: caxa, xalma, xeme, ximia, roxo, xugo: que salen de capsa, sagma, semis, roseus, succus: de suerte que exceptuando la $s$ de otras qualesquiera letras que se deriven los vocablos, parece que se debe usar de la $j$, para evitar confusiones (Conink, h. 1716: $479^{47}$ ).

El trueque de sibilantes, que se produjo en algunas palabras con [s] latina, se explica por la influencia del árabe, idea tomada también de Aldrete ${ }^{48}$ :

${ }^{47}$ Cfr. Aldrete (1972 [1606]: 217): "La S, tiene el sonido mui cercano a la X, porque esta letra vale lo, que $\mathrm{C}$, i $\mathrm{S}$, i la $\mathrm{c}$, vimos quan cercana es a la $\mathrm{g}$, por lo qual algunos en lugar de $\mathrm{x}$, escriuian g, s, [...] pero los nuestros la, s, Latina mudaron en g, i en x [...] i de Capsa, roseo, sagma, Salone, sapone, semis, sepia, Setabi, Simone, Sinapi, succosus, Sucro, dezimos caxa, roxo, xalma, Xalon, xabon, xeme, xibia, Xatiua, Ximon, ximia, xenable [...]. Parece pegado de los Araues, que de ordinario los de aquella lengua mudan la s, en x, i a las passas, dicen paxas".

${ }^{48}$ Véase, en la nota anterior, la transcripción del pasaje de Aldrete. 
A esto se allega que como los Españoles tomamos la pronunciacion gutural de los Arabes, y estos (como advierte el Doctor Alderete) $(* 49)$ pronuncian las ss. como $x$, y por decir passas, dicen paxas es mas que congruente la conversion de la $s$ en $x$, y no en $j$ (Conink, h. 1716: 480).

Esta apreciación se mantiene en el "Discurso proemial de la orthographía de la Lengua Castellana", donde se omite la referencia a Aldrete:

Tambien se debe usar de la $x$, y no de la $j$ quando las voces tienen en su orígen s: como Caxa, Dexar, Xabón, Xugo, Xeme, que salen de Capsa, Deserere, Sapo, Succus, Semipes: y la razón es, porque la $s$ tiene el sonído mui parecido al de la $x$ : y como los Españóles tomamos de los Arabes la pronunciación guturál, y estos pronúncian las ss como $x$, es naturál la conversión de la $s$ en $x$, y no en $j$ " (Real Academia Española, 1990 [1726]: LXXIV).

En el fragmento anterior parece sostenerse la idea, procedente de Aldrete, de que $<x>$ y $<j>$ se empleaban para representar pronunciaciones distintas. En cambio, dicha diferencia no se reconoce ya en el Diccionario de Autoridades, cuando en la entrada para $<j>$ se indica que "su pronunciación es gutural, como la própria y natural de la X".

El mantenimiento de $<x>$ para representar el sonido de una sibilante de origen romance tenía el inconveniente de que esta letra se emplea también para representar [ks] en los latinismos. Esta particularidad se resuelve en el Diccionario de Autoridades mediante la explicación de cómo deben pronunciarse los cultismos. Por ejemplo, en la entrada examen, se declara que "es voz Latina Examen, y se pronuncia la x como cs".

A diferencia de lo que ocurre con $\langle\mathrm{x}\rangle \mathrm{y}<\mathrm{j}\rangle$, apenas se encuentran reflexiones sobre la distinción entre $<\mathrm{g}>\mathrm{y}<\mathrm{j}>$. En su discurso manuscrito, Conink solo se refirió al empleo extendido de $<\mathrm{g}>$ ante $<\mathrm{e}$, i $>$, que consideraba debía excusarse en los derivados de palabras con $\langle x\rangle$ o con $\langle j\rangle$, para los que convendría mantener la grafía de la palabra simple con el fin de no desfigurar su origen:

la $g$, antes de las vocales $e, i,[\ldots]$ solo debe retenerse en el preciso uso de sus primitivos ó derivados; v.g. eligir, elige, regir, rige \& sin que deba extenderse á los derivados de la $j$, y $x$, quando se siguen las referidas dos vocales $e$, $i$ : v.g. dexar, vexar, aconsejar, motejar, escribiendo dege, vege, aconsege, motege, \&, porque esto es alterar conocidamente los primitivos, sin necessidad, y sin el menor fundamento, y trastornar, y confundir la Lengua mas de lo que está (Conink, h. 1716: 476) ${ }^{50}$.

${ }^{49}$ En el margen izquierdo se incluye la nota siguiente, “(*) Lib. $3 .^{\circ}$ c. 12 ”, con la referencia a la localización de la referencia en el texto de Aldrete.

${ }^{50} \mathrm{Cfr}$. el siguiente fragmento del "Discurso proemial": "La $g$ es sola antes de las vocáles $e, i$, porque en las otras tres no es aspirada, ò guturál: u assi unicamente se debe usar de $g$ en sus primitivos y derivados, como son Elegir, Regir, Colegir, Afligir, Proteger, Coger, \&c. escribiendo Elige, Eligió, Rige, Colige, Aflige, Protegía, Protegió, Cogía, Cogió, \&c. sin extenderse a los derivados de la $j$, y la $x$ " (Real Academia Española, 1990 [1726]: LXXIV). 


\section{5. $\langle q>\sim<c>$}

Para distinguir los usos de $<\mathrm{c}>$ y de $<\mathrm{q}>$ seguidas de $<\mathrm{u}>$, la Academia Española optó también por establecer un criterio etimológico. Conink reconocía que diversos autores habían considerado el uso de $<q>$ como superfluo cuando no representaba $/ \mathrm{ke} /$, /ki/ — con las grafías <que $>$ y $<q u i>$ —. En la versión manuscrita de su tratado se refería a la opinión de Antonio de Nebrija ${ }^{51}$, quien, no "la incluye en el Alphabeto Castellano", pero "declara la precision de su uso en las voces eloquencia, eloquente y eloquentemente" 52 (Conink, h. 1716: 482).

El uso de $<\mathrm{q}>$ etimológica por parte de Nebrija constituye un argumento de autoridad: se emplea para apoyar el mantenimiento de la distinción gráfica entre $<\mathrm{c}>$, "para las palabras que se derivan de la $c$, como cuajo, ascua, pascua", y $<\mathrm{q}>$, para "todas las voces que en su origen la tienen, como qual, quatro, quaderno" 53 (Conink, h. 1716: 482).

Esta distinción se mantuvo en el "Discurso proemial"54, donde ya no se aludía a Nebrija, sino solo a los autores que proponen la sustitución de $<\mathrm{q}>$ por $<\mathrm{c}>$ o por $<\mathrm{k}>^{55}$. La Academia fijó muy pronto la regla para mantener el uso de $<\mathrm{q}>$ en palabras derivadas de un étimo latino con $\langle\mathrm{q}\rangle$, a raíz de la discusión del 16 de mayo de 1715 sobre el lugar que debía ocupar la voz cotidiano. González de Barcia defendió que debía estar entre las voces de la $C$, pero la Academia, atendiendo a la etimología "conforme a la regla general"56 (Actas), decidió que se incluyera solo la remisión "Cotidiano véase Quotidiano" (Actas y Diccionario de Autoridades, s. v.). En consecuencia,

También se resolvió reservar para la letra $Q$ muchas voces que venían en dicha lista empezadas con Qua, como Quaresma, Qualquiera, Quartel, \&c. que según su origen deben escribirse con $Q$, aunque algunos autores que se

${ }^{51}$ Cfr. la advertencia de Nebrija (1989 [¿1495?]): f. aiiij') en el "Prólogo" a su Vocabulario español-latino: "para escrivir el son proprio de la. c. cuando se siguen. e. o. i. usamos de qu.".

52 Todas estas formas aparecen en el Vocabulario español-latino de Nebrija (h. 1495), tal y como puede constatarse en Nieto Jiménez y Alvar Ezquerra (2007: s. vv. elocuencia, elocuente y elocuentemente).

${ }^{53}$ Como recuerda Sánchez-Prieto Borja (1998: 122), "Qua- inicial tónico fue usual durante toda la Edad Media, y aun corriente en los impresos del Siglo de Oro: qual, quanto, quando, quatro".

${ }^{54}$ En este texto, se defiende mantener la $\langle\mathrm{q}>$ "porque assi no se confunden los orígenes de las voces, y se distinguen las que salen de la $C$ : como Cuajo, Cuenta, de las que vienen de la $Q$ : como Qual, Qüestión, que es la basa principál sobre que estriba la Orthographía" (Real Academia Española, 1990 [1726]: LXXV).

55 Cfr. Real Academia Española (1990 [1726]: LXXIV): "En quanto à la $Q$, y su uso hai tambien entre los Autóres variedád, porque algunos la repútan por inútil, assi por no usarse sola, sino acompañada de la $u$ antes de otra vocál, como porque sus voces se pueden suplir perfectamente con la $C$, y con la $K$ ".

${ }^{56}$ La referencia a la "regla general" alude a la directriz que incluía la Planta sobre la necesidad de acomodar la ortografía a los orígenes de las palabras. Véase sobre ello lo apuntado en $\S 2$. 
citaron las usen con $C$. Y que se dejen solo en la letra $C$ las que tocan a ella según sus etimologías, como Cuajada, Cuajar, \&c. (Actas, 16-V-1715).

\section{6. $\langle g\rangle \sim\langle h\rangle$ ante $\langle u\rangle$}

El "Discurso proemial de la orthographía de la Lengua Castellana" termina el apartado dedicado a "las letras unísonas" con una reflexión sobre los usos de $<$ g $>$ y de $<$ h $>$ ante $<$ u $>$ que no aparece en la versión manuscrita del tratado de Conink. Se constata la existencia de una pronunciación similar de voces como "Agüero, Pingüe, Degüello, Regüeldo" у "Hueco, Huebra, Huevo, Huella, y Huerta", que se resolvió atendiendo a la etimología de las palabras, pues se recomendó "escribir con $G$ las que las tienen en su orígen, y con $H$ las que no las tienen” (Real Academia Española, 1990 [1726]: LXXV).

\section{CONCLUSIONES}

Las palabras de Adrián Conink para cerrar su "Discurso de la Orthographía" escrito hacia 1716 resumen muy bien la intención de los trabajos realizados por los primeros académicos en torno a la fijación gráfica:

El deseo del acierto estimulado de la obligacion que reconozco á esta grande y Real Academia, han impelido mi agradecimiento á formar estos apuntamientos, que sujeto gustoso á la censura de qualquiera de sus individuos; y porque la experiencia me ha enseñado la gran distancia que hai de hablar naturalmente como hombre, á escribir con perfeccion lo que se habla; y que es error vano y vulgar presumir que la propriedad y pureza de las voces, y sus significados, y el modo verdadero de escribirlas se adquiere sin la debida reflexion y estudio, aunque la naturaleza, como maestra de la habla comunique á todos las palabras necesarias para significar lo que quieren dar á entender; cierro el discurso con lo que empezó el suyo de la Lengua Castellana el insigne Ambrosio de Morales: "que si es una buena parte de la prudencia en los hombres saber bien el Lenguage en que nacieron", no es menos loable, y digno de aprecio saberle escribir con la perfeccion, y puntualidad que le compete (Conink, h. 1716: 484-485).

Bajo estas afirmaciones subyace el convencimiento de que la escritura de las lenguas no puede limitarse al intento por reproducir sus manifestaciones orales. Para "escribir con perfeccion lo que se habla" se requiere de "reflexion y estudio" (Conink, h. 1716: 484-485). Son los textos escritos los que, como ya señalaba Ambrosio de Morales en su Discurso sobre la lengua castellana - recordado por Conink (h. 1716) en diversos pasajes - deben contribuir a asentar modelos lingüísticos. De la lengua escrita parte la versión manuscrita del 
"Discurso de la Orthographía" de Conink cuando se plantea como un problema la heterogeneidad de los usos gráficos constatada en las autoridades. La falta de modelos gráficos coherentes y generalmente aceptados es lo que provocó la redacción de los primeros principios de ortografía de la Academia, que optó en la definición de sus reglas $-\mathrm{y}$ en consonancia con el modelo propuesto por la Académie Française - por soluciones en su mayoría cercanas a los orígenes de las palabras, aunque en la práctica debiera combinar el respeto por las etimologías con los criterios del uso extendido y de la pronunciación.

El análisis de los discursos de Bartolomé Alcázar y de Adrián Conink conservados en el ms. 112 de la Biblioteca de la Real Academia Española ha permitido poner de relieve algunas de las motivaciones que explican los criterios de fijación gráfica propuestos por la Corporación en su primer Diccionario. Ha podido comprobarse cómo en los textos de Alcázar y de Conink se encuentran aspectos que más adelante se desarrollarán en el "Discurso proemial de la orthographía de la Lengua Castellana”, tales como el valor de los usos gráficos y de la etimología por encima de la pronunciación, el respeto por el alfabeto latino o la fijación de la ortografía como una necesidad para poder competir con otras lenguas romances. Asimismo, se ha demostrado el interés del texto manuscrito de Conink para la historia de la ortografía española, porque esta versión incipiente del primer tratado ortográfico de la Academia permite descubrir algunas de sus fuentes (no citadas en el "Discurso proemial") y, sobre todo, porque se trata de una muestra muy significativa del interesante proceso de búsqueda de modelos de lengua válidos para la fijación ortográfica. De este modo, el texto escrito por Conink hacia 1716 plantea, para rebatirlas, las posibilidades de tener en cuenta la pronunciación, la lengua de la Corte o el habla de un determinado dialecto, y halla en los usos gráficos consolidados y en la etimología los principios que vertebrarán las primeras reglas ortográficas propuestas por la Real Academia Española.

\section{BIBLIOGRAFÍA}

Académie Française (1997 [1694]): "Préface" a Le Dictionnaire de l'Académie Françoise, en Bernard Quemada (dir.), Les préfaces du “Dictionnaire de l'Acádemie Française” (16941992), Paris, Honoré Champion, pp. 27-51.

Alcázar, Bartolomé (1715): Sobre si la Z es letra castellana, en ms. 112 de la Biblioteca de la Real Academia Española, pp. 114-120.

Alcoba, Santiago (2012): "El proceso de fijación ortográfica de las palabras en los DRAE”, en Gloria Clavería, Margarita Freixas, Marta Prat y Joan Torruella (eds.), Historia del léxico: perspectivas de investigación, Madrid/Frankfurt, Iberoamericana/Vervuert, pp. 273-302.

Aldrete, Bernardo J. de (1972 [1606]): Del origen y principio de la lengua castellana o romance que hoy se usa en España, Lidio Nieto Jiménez (ed. facsimilar y estudio), Madrid, CSIC.

Alemán, Mateo (1609): Ortografía castellana, Méjico, Jerónimo Balli. 
Aliaga Jiménez, José L. (1994): El léxico aragonés en el "Diccionario de autoridades" (Real Academia Española), Zaragoza, Institución "Fernando el Católico".

Aliaga Jiménez, José L. (1997): Contribución al estudio de las voces aragonesas en las ediciones del Diccionario de la Real Academia española (Lexicografía y diversidad geolingüística), microfichas, Zaragoza, Prensas Universitarias de Zaragoza.

Aliaga Jiménez, José L. (2000): Aspectos de lexicografía española. El léxico aragonés en las ediciones del diccionario académico, Zaragoza, Institución "Fernando el Católico"/Excma. Diputación de Zaragoza.

Alvar Ezquerra, Manuel (1993 [1991]): "Los aragonesismos en los primeros diccionarios académicos", en Manuel Alvar Ezquerra, Lexicografía descriptiva, Barcelona, Biblograf, pp. 333341.

Álvarez de Miranda, Pedro (2000): "La lexicografía académica de los siglos XVIII y XIX”, en Ignacio Ahumada (ed.), Cinco siglos de lexicografía del español. IV Seminario de Lexicografía Hispánica (Jaén, 17 al 19 de noviembre de 1999), Jaén, Universidad de Jaén, pp. 35-61.

Álvarez de Miranda, Pedro (2004): "Quevedo en la lexicografía española", Edad de Oro, XXIII, pp. 389-416.

Azorín Fernández, Dolores (2006): "Hacia la norma del español moderno. La labor reguladora de la Real Academia Española", Alicante, Biblioteca Virtual Miguel de Cervantes, disponible en $<$ http://www.cervantesvirtual.com/obra/hacia-la-norma-del-espaol-moderno-la-labor-reguladorade-la-real-academia-espaola-0/>.

Blecua, José M. (2006): Principios del Diccionario de Autoridades, discurso leído el día 25 de junio de 2006 en su recepción pública por el Excmo. Sr. D. José Manuel Blecua, y contestación del Excmo. Sr. D. José Antonio Pascual, Madrid, Real Academia Española.

Bravo Grajera, Gonzalo (1634): Breve discurso en que se modera la nueva Orthographia de España, Madrid, Francisco Martínez.

Bustos Tovar, José J. de (1988): "Las propuestas ortográficas de Gonzalo Correas", Dicenda: Cuadernos de filología hispánica, 16, pp. 41-62.

Cabrera, Luis (2005): "Sobre el principio etimológico en la ortografía castellana", en Palabras, norma, discurso: en memoria de Fernando Lázaro Carreter, Luis Santos Río (coord.), Salamanca, Universidad de Salamanca, pp. 215-224.

Cala Carvajal, Rafael (2001-2002): "La coherencia en lexicografía. El caso de algunos indoamericanismos en el Diccionario de Autoridades (1726-1739)", Revista de Lexicografía, VIII, pp. 7-24.

Candelas Colodrón, Manuel Á. (2004): "Quevedo y el Diccionario de Autoridades", en Lía Schwartz (ed.), Studies in honor of James O. Crosby, Newark (Delaware), Juan de la Cuesta, pp. 69-89.

Catalán, Diego (1989): "En torno a la estructura silábica del español de ayer y del español de mañana”, en Diego Catalán, El español. Orígenes de su diversidad, Madrid, Paraninfo, pp. 77-104.

Carriscondo Esquivel, Francisco M. (2006): "Vincencio Squarzafigo (1670-1737), Boletín de la Real Academia Española, LXXXVI, pp. 241-294.

Carriscondo Esquivel, Francisco M. (2009): "En los orígenes del método colegiado académico: el "Papel de reparos" al Diccionario (1731)", Bulletin hispanique, CXI: 1, pp. 109-140.

Catach, Nina (2001): Histoire de l'orthographe française, Renée Honvault avec la collaboration de Irène Rosier-Catach (ed. posthume), Paris, Honoré Champion.

Conink, Adrián (h. 1716): "Discurso de la Orthographía de la lengua castellana", en ms. 112 de la Biblioteca de la Real Academia Española, pp. 410-485.

Coromines, Joan y José A. Pascual (2012 [1980-1991]): Diccionario crítico etimológico castellano e hispánico, Gloria Clavería (dir.) y Joan Torruella (coord.), Madrid, Gredos, CD-ROM.

Esteve Serrano, Abraham (1982): Estudios de teoría ortográfica del español, Murcia, Universidad de Murcia. 
Ferrer del Río, Antonio (1865): "Reales Academias", en Apéndice a la historia de las órdenes de caballería, Madrid, Imprenta de Tomás Rey, pp. 77-106.

Freixas Alás, Margarita (2003): Las autoridades en el primer diccionario de la Real Academia Española, tesis doctoral, Bellaterra, Universitat Autònoma de Barcelona, disponible en $<\mathrm{http}$ // /www.tdx.cat/bitstream/handle/10803/4866/mfa1de2.pdf?sequence $=4>$.

Freixas Alás, Margarita (2010): Planta y método del Diccionario de Autoridades. Orígenes del método lexicográfico de la Real Academia Española (1713-1739), Anexo de la Revista de Lexicografía 14, Coruña, Universidade da Coruña.

Fries, Dagmar (1989): “Limpia, fija y da esplendor". La Real Academia Española ante el uso de la lengua (1713-1973), Madrid, SGEL.

García Santos, Juan Felipe (2011): "3. La Academia y la ortografía. 3.1. El Diccionario de Autoridades", en El castellano y su codificación gramatical, III, De 1700 a 1835, José J. Gómez Asencio (dir.), [Burgos]: Fundación Instituto Castellano y Leonés de la Lengua, pp. 457-465.

González Ollé, Fernando (2002): "El habla cortesana, modelo principal de la lengua española", Boletín de la Real Academia Española, LXXXII, pp. 153-231.

González Ollé, Fernando (2014): La Real Academia Española en su primer siglo, Madrid, Arco/Libros.

Instituto de Investigación Rafael Lapesa de la Real Academia Española (2013): Corpus del Nuevo diccionario histórico (CDH), <http://web.frl.es/CNDHE> [consulta: julio de 2013].

Jiménez Ríos, Enrique (2008): "La actitud de la Real Academia Española para la inclusión de la etimología en el diccionario", Revista de Filología Española, LXXXVIII, 2, pp. 297-324.

Lara, Luis Fernando (2000): "La nueva Ortografía de la Academia y su papel normativo", Nueva Revista de Filología Hispánica, XLIII, pp. 1-23.

Lázaro Carreter, Fernando (2000 [1972]): "El primer diccionario de la Academia", en Fernando Lázaro Carreter, Estudios de lingüística, Barcelona, Crítica, pp. 83-148.

López de Velasco, Juan (1582): Orthographia y pronunciación castellana, Burgos, [s.i.].

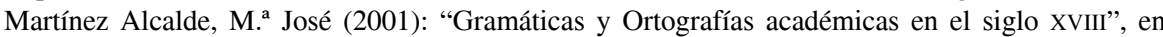
E. F. K. Koerner y H. J. Niederehe (eds.), History of Linguistics in Spain, Amsterdam, John Benjamins, pp. 195-214.

Martínez Alcalde, M. ${ }^{a}$ José (2007): "Lexicografía y codificación ortográfica en el siglo XVIII", en Historia de la lexicografía española, Mar Campos Souto, Rosalía Coteki García y José Ignacio Pérez Pascual (eds.), Coruña, Universidade da Coruña, Anexo de la Revista de Lexicografía 7, pp. 111-118.

Martínez Alcalde, M. ${ }^{a}$ José (2010): La fijación ortográfica del español: norma y argumento historiográfico, Bern, Peter Lang.

Martínez Alcalde, M. ${ }^{a}$ José (2012): "Ortografía", en Reflexión lingüística y lengua en la España del XIX. Marcos, panoramas y nuevas aportaciones, Alfonso Zamorano (ed. y coord.), München, Lincom Europa, pp. 95-115.

Miranda, Juan de (1566): Osservationi della lingua castigliana, Venezia, Giolito de' Ferrari.

Montero Curiel, Pilar (2006): "Los dialectalismos extremeños en el Diccionario de Autoridades", Anuario de Estudios Filológicos, XXIX, pp. 187-204.

Nebrija, Antonio de: (1989 [¿1495?]): Dictionarium ex hispaniensi in latinum sermonem o Vocabulario español-latino, $2^{\mathrm{a}}$ ed., Salamanca/Madrid, Real Academia Española/Asociación de Amigos de la Real Academia Española.

Nieto Jiménez, Lidio y Manuel Alvar Ezquerra (2007): Nuevo tesoro lexicográfico del español (s. XIV-1726), Madrid, Arco/Libros.

Pérez Goyena, Antonio (1922): "Contribución de los jesuítas al Diccionario de Autoridades", Razón y Fe, 63, pp. 458-481.

Real Academia Española (1713): Planta y methodo qve, por determinacion de la Academia Española, deben observar los academicos en la composicion del nuevo Diccionario de la Lengua Castellana; a fin de consegvir su mayor uniformidad, Madrid, Imprenta Real, por José Rodríguez y Escobar. 
Real Academia Española (1713-1739): Actas, Manuscrito con los resúmenes de las juntas académicas conservado en el Archivo de la Real Academia Española.

Real Academia Española (1990 [1726]): "Discurso proemial de la Orthographía de la Lengua Castellana", en Diccionario de Autoridades, Madrid, Gredos, pp. LXI-LXXXIV.

Real Academia Española (1990 [1726-1739]): Diccionario de Autoridades, Madrid, Gredos.

Real Academia Española (2010 [1713-1726]): "Planta del Diccionario de Autoridades aprobada por la Real Academia Española (Actas, 2-XII-1713) y publicada en los "Preliminares" del primer tomo del repertorio lexicográfico (1726)", en Margarita Freixas, Planta y método del Diccionario de Autoridades. Orígenes del método lexicográfico de la Real Academia Española (1713-1739), Anexo de la Revista de Lexicografía 14, Coruña, Universidade da Coruña, pp. 449-456.

Real Academia Española (2013 [1726-1739]): Diccionario de Autoridades, disponible en <http:// www.rae.es>.

Rivas Zancarrón, Manuel (2010), "El impacto de las reformas ortográficas en la tradición escrita entre 1750 y 1850 ", en Victoriano Gaviño Rodríguez y Fernando Durán López (eds.), Gramática, canon e historia literaria (1750 y 1850), Madrid, Visor, pp. 327-348.

Rosenblat, Ángel (1951): "Las ideas ortográficas de Bello", en Obras completas de Andrés Bello, Caracas, Ministerio de Educación, tomo V, pp. IX-CXXXVIII.

Ruiz Pérez, Pedro (1993): "El Discurso sobre la lengua castellana de Ambrosio de Morales", Revista de Filología Española, LXXIII, 3, pp. 357-378.

Ruhstaller, Stefan (2002): "Variantes léxicas en el Diccionario de Autoridades. Descripción lingüística y juicios normativos", en Actas del V Congreso Internacional de Historia de la Lengua Española, M. ${ }^{\mathrm{a}}$ Teresa Echenique Elizondo y Juan Sánchez Méndez (coords.), Madrid, Gredos, tomo II, pp. 2.321-2.329.

Salvador Rosa, Aurora (1985): "Las localizaciones geográficas en el Diccionario de Autoridades", Lingüística Española Actual, VII, pp. 103-139.

Salvador, Gregorio y Juan R. Lodares (2001 [1996]): Historia de las letras, Madrid, EspasaCalpe.

Sánchez-Prieto Borja, Pedro (1998): Cómo editar los textos medievales, Madrid, Arco/Libros.

Sarmiento, Ramón (1978): "Aportación a la historia de la ortografía de la RAE", Módulo 3. Revista de la Universidad Autónoma de Madrid, 2, pp. 29-40.

Sarmiento, Ramón (2001): La norma ortográfica de la Real Academia Española (1741): aportación al estudio del español moderno, Madrid, Ediciones de Cultura Hispánica/Agencia Española de Cooperación Internacional.

Seco, Manuel (1988): "El léxico hispanoamericano en los diccionarios de la Academia Española", Boletín de la Real Academia Española, LXVIII, CCXLIII, pp. 85-98.

Serianni, Luca y Pietro Trifone (1993): Storia della lingua italiana, Torino, Giulio Einaudi, vol. I.

Torrens Álvarez, María Jesús (2006): "Las grafías de sibilantes dentoalveolares en la escritura anterior a la "norma alfonsí"”, Filología y lingüística: estudios ofrecidos a Antonio Quilis, Madrid, CSIC, vol. 2, pp. 1385-1404.

Villalón, Cristóbal de (1558): Gramática castellana, Anvers, Guillermo Simón.

Zamora Vicente, Alonso (1999): La Real Academia Española, Madrid, Espasa-Calpe.

Fecha de recepción: 2 de junio de 2014

Fecha de aceptación: 10 de diciembre de 2014 